\title{
Synthesis of monomeric and polymeric alkali and alkaline earth metal complexes using a phosphinoselenoic amide ligand in metal coordination sphere
}

\author{
JAYEETA BHATTACHARJEE, RAVI K KOTTALANKA, HARINATH ADIMULAM \\ and TARUN K PANDA* \\ Department of Chemistry, Indian Institute of Technology Hyderabad, Ordnance Factory Estate, \\ Yeddumailaram 502 205, Telangana, India \\ e-mail: tpanda@iith.ac.in
}

MS received 17 March 2014; revised 24 April 2014; accepted 14 May 2014

\begin{abstract}
We report the monomeric complexes of magnesium and calcium of composition $\left[\mathrm{M}(\mathrm{THF})_{\mathrm{n}}\left\{\eta^{2}-\right.\right.$ $\left.\left.\mathrm{Ph}_{2} \mathrm{P}(\mathrm{Se}) \mathrm{N}\left(\mathrm{CMe}_{3}\right)\right\}_{2}\right][\mathrm{M}=\mathrm{Mg}(3), \mathrm{n}=1$ and $\left.\mathrm{M}=\mathrm{Ca}(\mathbf{4}), \mathrm{n}=2)\right]$ and polymeric complexes of potassium and barium of composition $\left[\mathrm{K}(\mathrm{THF})_{2}\left\{\mathrm{Ph}_{2} \mathrm{P}(\mathrm{Se}) \mathrm{N}\left(\mathrm{CMe}_{3}\right)\right\}\right]_{\mathrm{n}}(\mathbf{2})$ and $\left[\mathrm{K}(\mathrm{THF}) \mathrm{Ba}\left\{\mathrm{Ph}_{2} \mathrm{P}(\mathrm{Se}) \mathrm{N}\left(\mathrm{CMe}_{3}\right)\right\}_{3}\right]_{\mathrm{n}}(\mathbf{5})$ respectively. The potassium complex 2 was readily prepared by the reaction of potassium bis(trimethylsilyl)amide with phosphinoselenoic amide ligand (1) at ambient temperature. The calcium complex $\mathbf{4}$ was prepared by two synthetic routes: in the first method, commonly known as salt metathesis reaction, the potassium complex 2 was made to react with alkaline earth metal diiodide at room temperature to afford the corresponding calcium complex. The metal bis(trimethylsilyl)amides were made to react with protic ligand $\mathbf{1}$ in the second method to eliminate the volatile bis(trimethyl)silyl amine. The magnesium complex $\mathbf{3}$ and barium complex $\mathbf{5}$ were prepared only through the first method. Solid-state structures of all the new complexes were established by single crystal X-ray diffraction analysis. The smaller ionic radii of $\mathrm{Mg}^{2+}(0.72 \AA)$ and $\mathrm{Ca}^{2+}(0.99 \AA)$ ions form the monomeric complex, whereas the larger ions $\mathrm{K}^{+}(1.38 \AA)$ and $\mathrm{Ba}^{2+}(1.35 \AA)$ were found to form onedimensional polymeric complexes with monoanionic ligand 1. Compound $\mathbf{2}$ serves an example of magnesium complex with a $\mathrm{Mg}-\mathrm{Se}$ direct bond.
\end{abstract}

Keywords. Magnesium; calcium; barium; potassium; phosphorus; selenium.

\section{Introduction}

To date, the chemistry of alkaline earth metals is less developed when compared to magnesium chemistry, and the former are often termed 'sleeping beauties'., Among the alkaline earth metals ( $\mathrm{Mg}, \mathrm{Ca}, \mathrm{Sr}$ and $\mathrm{Ba}$ ), magnesium is exceptional; it was studied extensively by Grignard, who established that the organomagnesium reagent plays a significant role in synthetic inorganic and organic chemistry. ${ }^{3,4}$ In recent years, the chemistry of heavier alkaline earth metals has been well established and complexes of the alkaline earth metals are employed in various catalytic applications such as ring-opening polymerisation of various cyclic esters, ${ }^{5,6}$ polymerisation of styrene and dienes, ${ }^{7-9}$ and hydroamination and hydrophosphination reactions of alkenes and alkynes. ${ }^{10}$ Exploration of the structure and reactivity of alkaline earth metal species is one of the most important steps towards the design and development of efficient homogeneous catalysts. However, full realisation of

*For correspondence the catalytic potential of these elements still requires substantial advances in understanding their basic coordination and organometallic chemistry. To stabilise these extremely oxophilic and electropositive metals, a wide variety of nitrogen-based ancillary ligands, such as tris(pyrazolyl)borates, ${ }^{1}$ aminotroponiminates, ${ }^{11}$ $\beta$-diketiminates, ${ }^{12-14}$ iminopyrroles ${ }^{15-17}$ and 1,4-diaza1,3-butadiene ${ }^{18,19}$ have been introduced to prepare well-defined alkaline earth metal complexes, revealing that the catalytic activity and selectivity of the alkaline earth metal complexes can be controlled via the well-defined nitrogen-based ligand architecture. Another important application of alkaline earth metal chalcogenolates is in high temperature superconductors and ferroelectrics. In particular, alkaline earth metal oxide compounds are used as suitable precursors. ${ }^{20}$ Much less attention has been paid to the alkaline earth metal thiolates and selenates, although many heavier chalcogenates are known as potential dopants for chalcogen-based semiconductors. ${ }^{21}$ Chelating ligands with selenium as the donor atom to stabilise heavier alkaline earth metal complexes are rare. Over the 
last few years very few alkaline earth selenium-based complexes have been reported and structurally characterised. Among these are $\left[\mathrm{Mg}(\mathrm{SeMes"})_{2}(\mathrm{THF})_{2}\right]$ $\left(\mathrm{Mes} "=2,4,6-\mathrm{tBu}_{3} \mathrm{C}_{6} \mathrm{H}_{2}\right),{ }^{22}\left[\mathrm{M}(\mathrm{SeMes})_{2}(\mathrm{THF})_{4}\right](\mathrm{M}=$ $\mathrm{Ca}, \mathrm{Sr}, \mathrm{Ba}),{ }^{23-25}\left[\mathrm{Ca}\left\{\mathrm{CH}(\mathrm{Py})(\mathrm{Se}) \mathrm{PPh}_{2}\right\}_{2}\left(\mathrm{THF}_{2}\right]_{2}(\mathrm{Py}=\right.$ pyridine $)^{26}$ and $\left[(\mathrm{TMEDA})_{2} \mathrm{Ca}\left(\mathrm{SeSi}\left(\mathrm{SiMe}_{3}\right)_{3}\right)\right] .{ }^{27}$ Full structural characterisation of strontium selenides is even more scarce..$^{23,28}$ A complex with a bariumselenium bond is limited as structurally authenticated examples are mostly restricted to various sulphur derivatives: $\left[\left\{\left(\mathrm{H}_{2} \mathrm{O}\right)_{2} \mathrm{Ba}\left(\mathrm{tmtH}_{2}\right)_{2}\right\}_{\mathrm{n}}\right](\mathrm{tmt}=2,4$, 6-trimarcaptotriazine, $\left.\quad \mathrm{S}_{3} \mathrm{C}_{3} \mathrm{~N}_{3}\right),{ }^{29} \quad[([18]$ crown-6)Ba $\left(\right.$ hmpa)SMes $*$ [SMes*] $\left(\right.$ Mes* $\left.=2,4,6-t \mathrm{Bu}_{3} \mathrm{C}_{6} \mathrm{H}_{2}\right),{ }^{30}$ $\left[\mathrm{Ba}(\mathrm{hmpa})_{3}\{\mathrm{Na}-\mathrm{PhNNNNC}(\mathrm{S})\}_{2}\right],{ }^{31} \quad\left[\mathrm{Ba}-(\mathrm{hmpa})_{3}(\mathrm{C}\right.$ $\left.(=\mathrm{S}) \mathrm{NOPh}_{2}\right]^{32}$ and $\left[\mathrm{Ba}\left(\mathrm{SCMe}_{3}\right)_{2},{ }^{33}\left[\mathrm{Ba}(\mathrm{tmeda})_{2}(\mathrm{SeSi}\right.\right.$ $\left.\left.\left(\mathrm{SiMe}_{3}\right)_{3}\right)_{2}\right],{ }^{27}$ with only a few more examples being reported. Ruhlandt-Senge and colleagues reported barium selenoates like $\left[\mathrm{Ba}(\mathrm{THF})_{4}\left(\mathrm{SeMes}^{*}\right)_{2}\right]$, [([27] crown-6) $\left.\mathrm{Ba}(\mathrm{hmpa})_{2}\left(\mathrm{SMes}^{*}\right)_{2}\right],\left[\mathrm{Ba}(\mathrm{Py})_{3}(\mathrm{THF})\right.$ (SeTrip) $\left.\left.{ }_{2}\right\}_{2}\right]$ (Trip $=2,4,6 \quad i \mathrm{Pr}_{3} \mathrm{C}_{6} \mathrm{H}_{2}$ ), and $[\mathrm{Ba}([18]$ crown6)(SeTrip) $\left.)_{2}\right] ;{ }^{34}$ however the vast potential of this field of chemistry is yet to be developed. Recently, we reported heavier alkaline earth metal selenium containing complexes $\left[\mathrm{M}(\mathrm{THF})_{2}\left\{\mathrm{Ph}_{2} \mathrm{P}(\mathrm{Se}) \mathrm{N}\left(\mathrm{CHPh}_{2}\right)\right\}_{2}\right](\mathrm{M}=\mathrm{Ca}, \mathrm{Sr}$, $\mathrm{Ba})$ to enrich the field of heavier group 2 metal seleno complexes. ${ }^{35}$ In that work we showed that phosphinoselenoic amide ligands are capable of stabilising heavier alkaline earth metals through the formation of a selenium metal bond. In continuation of our focus on alkaline earth metal selenide complexes, we now explore the ligand's role in the nuclearity of metal complexes. Other research groups also reported various main group chemistry with phosphonic diamides ${ }^{t} \mathrm{BuP}(\mathrm{O})(\mathrm{NHR})_{2}$ and phosphonic triamides $\left(\mathrm{C}_{5} \mathrm{H}_{9} \mathrm{NH}\right)_{3} \mathrm{PO}^{36,37}$

In this context, detailed synthetic and structural features of the phosphinoselenoic amide ligand $\left[\mathrm{Ph}_{2} \mathrm{P}(\mathrm{Se}) \mathrm{N}\left(\mathrm{CMe}_{3}\right)\right](\mathbf{1})$, the corresponding monomeric magnesium and calcium complexes of molecular composition $\left[\mathrm{M}(\mathrm{THF})_{\mathrm{n}}\left\{\mathrm{Ph}_{2} \mathrm{P}(\mathrm{Se}) \mathrm{N}\left(\mathrm{CMe}_{3}\right)\right\}_{2}\right][\mathrm{M}=$ $\mathrm{Mg}(3), \mathrm{n}=1$ and $\mathrm{M}=\mathrm{Ca}(\mathbf{4}), \mathrm{n}=2)]$ and polymeric potassium and barium complexes $\left[\mathrm{K}(\mathrm{THF})_{2}\right.$ $\left.\left\{\mathrm{Ph}_{2} \mathrm{P}(\mathrm{Se}) \mathrm{N}\left(\mathrm{CMe}_{3}\right)\right\}\right]_{\mathrm{n}}$ (2) and $\left[\mathrm{K}(\mathrm{THF}) \mathrm{Ba}\left\{\mathrm{Ph}_{2} \mathrm{P}(\mathrm{Se})\right.\right.$ $\left.\left.\mathrm{N}\left(\mathrm{CMe}_{3}\right)\right\}_{3}\right]_{\mathrm{n}}(\mathbf{5})$ respectively are presented.

\section{Experimental}

\subsection{General information}

All manipulations of air-sensitive materials were performed with the rigorous exclusion of oxygen and moisture in flame-dried Schlenk-type glassware either on a dual manifold Schlenk line, interfaced to a high vacuum $\left(10^{-4}\right.$ torr $)$ line, or in an argon-filled M. Braun glove box. THF was pre-dried over a sodium wire and distilled under nitrogen from sodium and benzophenoneketyl prior to use. Hydrocarbon solvents (toluene and $n$-pentane) were distilled under nitrogen from $\mathrm{LiAlH}_{4}$ and stored in the glove box. ${ }^{1} \mathrm{H}$ NMR (400 $\mathrm{MHz}),{ }^{13} \mathrm{C}\left\{{ }^{1} \mathrm{H}\right\}(100 \mathrm{MHz})$ and ${ }^{31} \mathrm{P}\left\{{ }^{1} \mathrm{H}\right\}$ NMR (161.9 $\mathrm{MHz}$ ) spectra were recorded on a BRUKER AVANCE III-400 spectrometer. BRUKER ALPHA FT-IR was used for FT-IR measurement. Elemental analyses were performed on a BRUKER EURO EA at the Indian Institute of Technology Hyderabad. $\left[\mathrm{KN}\left(\mathrm{SiMe}_{3}\right)_{2}\right],{ }^{38}$ $\left[\mathrm{Ca}\left\{\mathrm{N}\left(\mathrm{SiMe}_{3}\right)_{2}\right\}_{2}(\mathrm{THF})_{2}\right]^{39,40}$ and $N$-tert-butyl-1,1diphenylphosphinamine $\left[\mathrm{Ph}_{2} \mathrm{PNHCMe}_{3}\right]^{41}$ were prepared according to published procedures. $\mathrm{MI}_{2}(\mathrm{M}=$ $\mathrm{Mg}, \mathrm{Ca}, \mathrm{Ba}$ ), were purchased from Sigma Aldrich and used without further purification.

\subsection{Synthesis of $\left[\mathrm{Ph}_{2} \mathrm{P}(\mathrm{Se}) \mathrm{N}\left(\mathrm{CMe}_{3}\right)\right](\mathrm{1})$}

$N$-tert-butyl-1,1-diphenylphosphinamine (1.50 g, 5.82 mol) and elemental selenium (900 mg, $12.0 \mathrm{~mol})$ were heated to $60^{\circ} \mathrm{C}$ in THF $(10 \mathrm{~mL})$ for 12 hours. Excess selenium metal was filtered through a G4 frit to collect the yellow colour filtrate. After evaporation of solvent from filtrate in vacuo, a light yellow solid residue was obtained. Compound $\mathbf{1}$ was re-crystallised from THF at room temperature.

Yield: $1.85 \mathrm{~g}, 94 \%$.

${ }^{1} \mathrm{H}$ NMR $\left(400 \mathrm{MHz}, \mathrm{CDCl}_{3}\right): \delta 8.02-8.08(\mathrm{~m}, 4 \mathrm{H}$, $\operatorname{Ar} H), 7.40-7.45(\mathrm{~m}, 6 \mathrm{H}, \operatorname{Ar} H), 1.36\left(\mathrm{~s}, 9 \mathrm{H}, \mathrm{CH}_{3}\right)$, 2.22 (br, $1 \mathrm{H}, \mathrm{N} H)$ ppm. ${ }^{13} \mathrm{C}\left\{{ }^{1} \mathrm{H}\right\}$ NMR $(100 \mathrm{MHz}$, $\left.\mathrm{CDCl}_{3}\right): \delta 136.3(\mathrm{P}$ attached $\mathrm{ArC}), 135.4(\mathrm{P}$ attached $\operatorname{ArC}), 131.8(\mathrm{P}$ attached $o-\operatorname{Ar} C$ ), 131.7 (P attached $o$ $\mathrm{ArC}$ ), 131.4 (P attached $p$-ArC), 128.3 (P attached $m$ $\mathrm{ArC}), 128.1$ (P attached $m$-ArC), $54.7\left(\mathrm{CMe}_{3}\right), 31.5$ $\left(\mathrm{CH}_{3}\right)$ ppm. ${ }^{31} \mathrm{P}\left\{{ }^{1} \mathrm{H}\right\}$ NMR (161.9 $\left.\mathrm{MHz}, \mathrm{CDCl}_{3}\right): \delta$ $46.33 \mathrm{ppm}$. FT-IR (selected data): $v=3216(\mathrm{~N}-\mathrm{H})$, $1433(\mathrm{P}-\mathrm{C}), 993(\mathrm{P}-\mathrm{N}), 535(\mathrm{P}=\mathrm{Se}) \mathrm{cm}^{-1}$. Elemental analysis: $\mathrm{C}_{16} \mathrm{H}_{20} \mathrm{NPSe}$ (336.26); Calculated: C $57.15 \mathrm{H}$ 5.99 N 4.17, Found: C 56.89 H 5.39 N 3.81.

\subsection{Synthesis of $\left[\mathrm{K}(\mathrm{THF})_{2}\left\{\mathrm{Ph}_{2} \mathrm{P}(\mathrm{Se}) \mathrm{N}\left(\mathrm{CMe}_{3}\right)\right\}\right]_{n}$ (2)}

In a $10 \mathrm{~mL}$ sample vial, ligand $\mathbf{1}(100 \mathrm{mg}, 0.296 \mathrm{mmol})$ and $\left[\mathrm{K}\left\{\mathrm{N}\left(\mathrm{SiMe}_{3}\right)_{2}\right\}\right](59.144 \mathrm{mg}, 0.296 \mathrm{mmol})$ were mixed together with $5 \mathrm{~mL}$ of THF. After 6 hours of stirring, a small amount of THF $(2 \mathrm{ml})$ and $n$-pentane $(2 \mathrm{~mL})$ were added to it and kept at $-40{ }^{\circ} \mathrm{C}$. After 24 hours, colourless crystals of compound 2 were obtained. 
Yield: $140 \mathrm{mg}, 90 \%$.

${ }^{1} \mathrm{H}$ NMR (400 MHz, $\left.\mathrm{C}_{6} \mathrm{D}_{6}\right): \delta 8.08-8.13(\mathrm{~m}, 4 \mathrm{H}, \operatorname{Ar} H)$, 6.90-7.09 (m, 6H, ArH), 1.29 (s, 9H, $\left.\mathrm{CH}_{3}\right) \mathrm{ppm}$, 3.46 (m, THF), 1.31 (m, THF) ppm. ${ }^{13} \mathrm{C}\left\{{ }^{1} \mathrm{H}\right\}$ NMR $\left(100 \mathrm{MHz}, \mathrm{C}_{6} \mathrm{D}_{6}\right): \delta 133.8(\mathrm{P}$ attached $\operatorname{ArC}), 133.7$ $(\mathrm{P}$ attached $\operatorname{ArC}), 132.2(\mathrm{P}$ attached $\mathrm{o}-\mathrm{ArC}$ ), 131.2 (P attached o-ArC), 130.1 (P attached p-ArC), 124.1 ( $\mathrm{P}$ attached $\mathrm{m}-\mathrm{ArC}$ ), 123.4 (P attached $\mathrm{m}-\mathrm{ArC}$ ), 77.1 (THF), $60.4\left(\mathrm{CMe}_{3}\right), 14.2\left(\mathrm{CH}_{3}\right), 25.6$ (THF) ppm. ${ }^{31} \mathrm{P}\left\{{ }^{1} \mathrm{H}\right\}$ NMR $\left(161.9 \mathrm{MHz}, \mathrm{C}_{6} \mathrm{D}_{6}\right): \delta 46.3 \mathrm{ppm}$. FT-IR (selected data): $v=1433(\mathrm{P}-\mathrm{C}), 992(\mathrm{P}-\mathrm{N}), 576(\mathrm{P}=\mathrm{Se})$ $\mathrm{cm}^{-1}$. Elemental analysis: $\mathrm{C}_{24} \mathrm{H}_{32} \mathrm{KNO}_{2} \mathrm{PSe}$ (515.54); Calculated: C 55.91 H 6.26 N 2.72, Found: C 55.36 H 5.92 N 2.43.

\subsection{Synthesis of $\left[\mathrm{Mg}(\mathrm{THF})_{n}\left\{\eta^{2}-\mathrm{Ph} h_{2} \mathrm{P}(\mathrm{Se}) \mathrm{N}\left(\mathrm{CMe}_{3}\right)\right\}\right.$} 2] (3)

In a $25 \mathrm{~mL}$ pre-dried Schlenk flask, compound $\mathbf{2}$ (186 mg, $0.36 \mathrm{mmol})$ was mixed with $\mathrm{MgI}_{2}$ (50 mg, $0.18 \mathrm{mmol}$ ) in $10 \mathrm{~mL}$ THF solvent at ambient temperature and stirred for 12 hours. The white precipitate of KI was filtered and the filtrate was evaporated in vacuo. The resulting white residue was further purified by washing with pentane $(3 \mathrm{~mL})$ and crystals suitable for X-ray analysis were grown from THF/pentane (1: 2 ratio) mixture at $-40^{\circ} \mathrm{C}$.

Yield: $118 \mathrm{mg}, 85 \%$.

${ }^{1} \mathrm{H}$ NMR (400 MHz, $\left.\mathrm{C}_{6} \mathrm{D}_{6}\right): \delta 8.17-8.23(\mathrm{~m}, 8 \mathrm{H}$, $\operatorname{ArH}), 6.98-7.15(\mathrm{~m}, 12 \mathrm{H}, \operatorname{Ar} H), 1.20\left(\mathrm{~s}, 18 \mathrm{H}, \mathrm{CH}_{3}\right)$ ppm. ${ }^{13} \mathrm{C}\left\{{ }^{1} \mathrm{H}\right\}$ NMR $\left(100 \mathrm{MHz}, \mathrm{C}_{6} \mathrm{D}_{6}\right): \delta 132.4(\mathrm{P}-$ $\operatorname{ArC}$ ), 132.3 (P-ArC), 131.3 (P attached o-ArC), 130.8 (P attached o-ArC), 128.3 ( $\mathrm{P}$ attached $\mathrm{p}-\mathrm{ArC}), 128$ ( $\mathrm{P}$ attached $\mathrm{m}-\mathrm{ArC}$ ), 127.8 ( $\mathrm{P}$ attached $\mathrm{m}-\mathrm{ArC}$ ), 55.0 $\left(\mathrm{CMe}_{3}\right), 31.4\left(\mathrm{CH}_{3}\right)$, ppm. ${ }^{31} \mathrm{P}\left\{{ }^{1} \mathrm{H}\right\}$ NMR (161.9 $\left.\mathrm{MHz}, \mathrm{C}_{6} \mathrm{D}_{6}\right): \delta 59.5 \mathrm{ppm}$. FT-IR (selected data): $v=$ $1436(\mathrm{P}-\mathrm{C}), 930(\mathrm{P}-\mathrm{N}), 570(\mathrm{P}=\mathrm{Se}) \mathrm{cm}^{-1}$. Elemental analysis: $\mathrm{C}_{40} \mathrm{H}_{54} \mathrm{MgN}_{2} \mathrm{O}_{2} \mathrm{P}_{2} \mathrm{Se}_{2}$ (839.02); Calculated: $\mathrm{C}$ 57.26 H 6.49 N 3.34, Found: C 56.83 H 5.97 N 3.01.

\subsection{Synthesis of $\left[(\mathrm{THF})_{n} \mathrm{Ca}\left\{\eta^{2}-\mathrm{Ph}{ }_{2} \mathrm{P}(\mathrm{Se}) \mathrm{N}\left(\mathrm{CMe}_{3}\right)\right\}\right.$ 2] (4)}

Route 1: In a $10 \mathrm{~mL}$ sample vial, two equivalents (100 mg, $0.296 \mathrm{mmol}$ ) of ligand 1 and one equivalent of $\left[\mathrm{Ca}\left\{\mathrm{N}\left(\mathrm{SiMe}_{3}\right)_{2}\right\}_{2}(\mathrm{THF})_{2}\right]$ were mixed together with $5 \mathrm{~mL}$ of THF. After 6 hours of stirring, another $2 \mathrm{~mL}$ of THF and $n$-pentane $(2 \mathrm{~mL})$ were added to it and kept at $-40{ }^{\circ} \mathrm{C}$. After 24 hours, colourless crystals were obtained.
Yield: $115.0 \mathrm{mg}, 90 \%)$.

Route 2: In a $25 \mathrm{~mL}$ pre-dried Schlenk flask, compound 2 (320 mg, $0.68 \mathrm{mmol}$ ) was mixed with $\mathrm{CaI}_{2}$ (100 mg, $0.34 \mathrm{mmol}$ ) in $10 \mathrm{~mL}$ THF solvent at ambient temperature and stirring continued for 12 hours. The white precipitate of KI was filtered off and filtrate was evaporated in vacuo. The resulting white residue was further purified by washing with pentane and crystals suitable for X-ray analysis were grown from $\mathrm{THF} /$ pentane (1: 2 ratio) mixture at $-40{ }^{\circ} \mathrm{C}$.

Yield: $270 \mathrm{mg}, 92 \%$.

${ }^{1} \mathrm{H}$ NMR (400 MHz, $\left.\mathrm{C}_{6} \mathrm{D}_{6}\right): \delta 8.12-8.17(\mathrm{~m}, 8 \mathrm{H}, \mathrm{Ar} H)$, 7.09-7.16 (m, 12H, ArH), 3.76 (m, THF), 1.49 (s, $\left.18 \mathrm{H}, \mathrm{CH}_{3}\right), 1.37$ (m, THF) ppm. ${ }^{13} \mathrm{C}\left\{{ }^{1} \mathrm{H}\right\}$ NMR $(100$ $\left.\mathrm{MHz}, \mathrm{C}_{6} \mathrm{D}_{6}\right): \delta 142.5(\mathrm{P}-\mathrm{ArC}), 141.8(\mathrm{P}-\mathrm{ArC}), 132.7$ (P attached o-ArC), 132.6 (P attached o-ArC), 129.7 ( $\mathrm{P}$ attached $\mathrm{p}-\mathrm{ArC}$ ), 127.5 (P attached $\mathrm{m}-\mathrm{ArC}$ ), 127.4 (P attached m-ArC), 68.7 (THF), $55.0\left(\mathrm{CMe}_{3}\right), 35.9$ $\left(\mathrm{CH}_{3}\right), 25.6$ (THF) ppm. ${ }^{31} \mathrm{P}\left\{{ }^{1} \mathrm{H}\right\}$ NMR $(161.9 \mathrm{MHz}$, $\left.\mathrm{C}_{6} \mathrm{D}_{6}\right): \delta 37.1 \mathrm{ppm}$. FT-IR (selected data): $v=1433$ $(\mathrm{P}-\mathrm{C}), 995(\mathrm{P}-\mathrm{N}), 581(\mathrm{P}=\mathrm{Se}) \mathrm{cm}^{-1}$. Elemental analysis: $\mathrm{C}_{44} \mathrm{H}_{62} \mathrm{CaN}_{2} \mathrm{O}_{4} \mathrm{P}_{2} \mathrm{Se}_{2}$ (942.90); Calculated: C 56.05 H 6.63 N 2.97, Found: C 55.77 H 6.32 N 2.58.

\subsection{Synthesis of $\left[\mathrm{K}(\mathrm{THF}) \mathrm{Ba}\left\{\mathrm{Ph}_{2} \mathrm{P}(\mathrm{Se}) \mathrm{N}\left(\mathrm{CMe}_{3}\right)\right\}_{3}\right]_{n}$}

In a $25 \mathrm{~mL}$ pre-dried Schlenk flask, potassium complex 2 (264 mg, $0.52 \mathrm{mmol}$ ) was mixed with $\mathrm{BaI}_{2}(100 \mathrm{mg}$, $0.26 \mathrm{mmol}$ ) in $10 \mathrm{~mL}$ THF solvent at ambient temperature and stirring continued for 12 hours. The white precipitate of KI was filtered and filtrate was evaporated in vacuo. The resulting white compound was further purified by washing with pentane and crystals suitable for X-ray analysis were grown from THF/pentane (1:2 ratio) mixture at $-40^{\circ} \mathrm{C}$.

Yield: $285 \mathrm{mg}, 90 \%$.

${ }^{1} \mathrm{H}$ NMR $\left(400 \mathrm{MHz}, \mathrm{C}_{6} \mathrm{D}_{6}\right): \delta 8.27-8.33(\mathrm{~m}, 12 \mathrm{H}$, $\mathrm{ArH}), 7.08-7.15(\mathrm{~m}, 18 \mathrm{H}, \operatorname{Ar} H), 1.27\left(\mathrm{~s}, 27 \mathrm{H}, \mathrm{CH}_{3}\right)$ ppm, 3.67 (m, THF), 1.51 (m, THF) ppm. ${ }^{13} \mathrm{C}\left\{{ }^{1} \mathrm{H}\right\}$ NMR $\left(100 \mathrm{MHz}, \mathrm{C}_{6} \mathrm{D}_{6}\right): \delta 132.3(\mathrm{P}$ attached $\operatorname{ArC})$, 132.2 ( $\mathrm{P}$ attached o-ArC), 132.1 (P attached o-ArC), 128.3 ( $\mathrm{P}$ attached $\mathrm{p}-\mathrm{ArC}$ ), 128 ( $\mathrm{P}$ attached $\mathrm{m}-\mathrm{ArC}$ ), 127.8 (P attached m-ArC), 68.7 (THF), $58.9\left(\mathrm{CMe}_{3}\right)$, 31.5 $\left(\mathrm{CH}_{3}\right), 25.6$ (THF) ppm. ${ }^{31} \mathrm{P}\left\{{ }^{1} \mathrm{H}\right\} \quad \mathrm{NMR}(161.9$ $\left.\mathrm{MHz}, \mathrm{C}_{6} \mathrm{D}_{6}\right): \delta 46.3 \mathrm{ppm}$. FT-IR (selected data): $v=$ $1433(\mathrm{P}-\mathrm{C}), 996(\mathrm{P}-\mathrm{N}), 576(\mathrm{P}=\mathrm{Se}) \mathrm{cm}^{-1}$. Elemental analysis: $\mathrm{C}_{56} \mathrm{H}_{73} \mathrm{BaKN}_{3} \mathrm{O}_{2} \mathrm{P}_{3} \mathrm{Se}_{3}$ (1326.39); Calculated: C 50.71 H 5.55 N 3.17, Found: C 50.23 H 5.11 N 2.74. 


\subsection{Single-crystal $x$-ray structure determinations}

Single crystals of compound $\mathbf{1}$ were grown from THF at room temperature and complexes 2-5 were grown from a solution of THF/pentane mixture (1:2) under inert atmosphere at a temperature of $-40^{\circ} \mathrm{C}$. In each case a crystal of suitable dimensions was mounted on a CryoLoop (Hampton Research Corp.) with a layer of light mineral oil and placed in a nitrogen stream at 150(2) K. All measurements were made on an Agilent Supernova X-calibur Eos CCD detector with graphitemonochromatic $\operatorname{MoK} \alpha(0.71073 \AA$ ) (for 1) and $\mathrm{Cu} \mathrm{K} \alpha$
(1.54184 A) (for 2, 3, 4 and 5) radiation. Crystal data and structure refinement parameters are summarised in table 1 . The structures were solved by direct methods (SIR92) ${ }^{42}$ and refined on $F^{2}$ by full-matrix leastsquares methods; using SHELXL-97. ${ }^{43}$ Non-hydrogen atoms were anisotropically refined. Hydrogen atoms were included in the refinement on calculated positions riding on their carrier atoms. The function minimised was $\left[\sum w\left(F \mathrm{o}^{2}-F \mathrm{c}^{2}\right)^{2}\right]\left(w=1 /\left[\sigma^{2}\left(F_{\mathrm{o}}^{2}\right)+\right.\right.$ $\left.\left.(a \mathrm{P})^{2}+b \mathrm{P}\right]\right)$, where $\mathrm{P}=\left(\operatorname{Max}\left(F_{\mathrm{o}}^{2}, 0\right)+2 F \mathrm{c}^{2}\right) / 3$ with $\sigma^{2}\left(F_{\mathrm{o}}^{2}\right)$ from counting statistics. The function $R_{1}$ and $w R_{2}$ were $\left(\Sigma\left\|F_{\mathrm{o}}|-| F_{\mathrm{c}}\right\|\right) / \Sigma\left|F_{\mathrm{o}}\right|$ and $\left[\Sigma w\left(F_{\mathrm{o}}^{2}-\right.\right.$

Table 1. Structural parameters for complexes 1-5.

\begin{tabular}{|c|c|c|c|c|c|}
\hline Crystal Parameters & 1 & 2 & 3 & 4 & 5 \\
\hline CCDC No. & 991038 & 991040 & 991042 & 991041 & 991039 \\
\hline Formula weight & 336.26 & 515.54 & 839.02 & 942.90 & 1326.39 \\
\hline$T(\mathrm{~K})$ & $150(2)$ & $150(2)$ & $150(2)$ & $150(2)$ & $150(2)$ \\
\hline$\lambda(\AA)$ & 0.71073 & 1.54184 & 1.54184 & 1.54184 & 1.54184 \\
\hline Crystal system & Orthorhombic & Monoclinic & Monoclinic & Triclinic & Triclinic \\
\hline Space group & $P 212121$ & P 21/c & $P 21 / \mathrm{c}$ & $P-1$ & $P-1$ \\
\hline$a(\AA)$ & $9.5205(3)$ & $11.2088(5)$ & $10.5224(4)$ & $9.0371(8)$ & $11.1136(6)$ \\
\hline$b(\AA)$ & $9.5544(3)$ & $24.0100(11)$ & $10.0241(3)$ & $10.3328(8)$ & $11.6984(7)$ \\
\hline$c(\AA)$ & $17.5037(6)$ & $10.8149(5)$ & $39.048(2)$ & $13.0838(8)$ & $24.9355(14)$ \\
\hline$\alpha\left({ }^{\circ}\right)$ & 90 & 90 & 90 & 88.7 & 87 \\
\hline$\beta\left(\left(^{\circ}\right)\right.$ & 90 & 11 & 93 & 75 & 82 \\
\hline$\gamma\left({ }^{\circ}\right)$ & 90 & 90 & 90 & 69 & 67 \\
\hline$V\left(\AA^{3}\right)$ & $1592.18(9)$ & $2573.9(2)$ & $4110.2(3)$ & $1104.36(15)$ & $2969.8(3)$ \\
\hline Z & 4 & 4 & 4 & 1 & 2 \\
\hline$D_{\text {calc }} \mathrm{g} \mathrm{cm}^{-3}$ & 1.403 & 1.330 & 1.356 & 1.418 & 1.483 \\
\hline$\mu\left(\mathrm{mm}^{-1}\right)$ & 2.446 & 4.155 & 3.402 & 4.131 & 9.007 \\
\hline$F(000)$ & 688 & 1068 & 1736 & 490 & 1336 \\
\hline $\begin{array}{l}\text { Theta range for } \\
\text { data collection }\end{array}$ & 2.43 to $25.77 \mathrm{deg}$ & 3.68 to $70.91 \mathrm{deg}$. & 4.21 to $70.74 \mathrm{deg}$. & 4.59 to $70.91 \mathrm{deg}$. & 4.09 to $70.59 \mathrm{deg}$. \\
\hline Limiting indices & $-11<=\mathrm{h}<=6$ & $-13<=\mathrm{h}<=13$ & $-12<=\mathrm{h}<=12$ & $-11<=\mathrm{h}<=10$ & $-13<=\mathrm{h}<=13$ \\
\hline- & $\begin{array}{l}-11<=\mathrm{k}<=10 \\
-20<=1<=12\end{array}$ & $\begin{array}{l}-29<=\mathrm{k}<=29 \\
-8<=1<=13\end{array}$ & $\begin{array}{l}-12<=\mathrm{k}<=11 \\
-47<=1<=35\end{array}$ & $\begin{array}{l}-12<=\mathrm{k}<=11 \\
-15<=1<=14\end{array}$ & $\begin{array}{l}-8<=\mathrm{k}<=14 \\
-30<=1<=30\end{array}$ \\
\hline $\begin{array}{l}\text { Reflections collected / } \\
\text { unique }\end{array}$ & $\begin{array}{l}3347 / 2379 \\
{[R(\text { int })=0.0206]}\end{array}$ & $\begin{array}{l}10691 / 4852 \\
{[R(\text { int })=0.0377]}\end{array}$ & $\begin{array}{l}16320 / 7738 \\
{[R(\text { int })=0.0369]}\end{array}$ & $\begin{array}{l}7548 / 4145 \\
{[R(\text { int })=0.0339]}\end{array}$ & $\begin{array}{l}22614 / 11197 \\
{[R(\text { int })=0.0570]}\end{array}$ \\
\hline $\begin{array}{l}\text { Completeness } \\
\text { to theta }\end{array}$ & $87.7 \%(25.77)$ & $97.6 \%(70.91)$ & $97.9 \%$ & $97.5 \%$ & $98.2 \%$ \\
\hline Absorption correction & $\AA$ & Multi-Scan & Multi-Scan & Multi-Scan & Multi-Scan \\
\hline $\begin{array}{l}\text { Max. and min. } \\
\text { transmission }\end{array}$ & 1.000 and 0.705 & $\begin{array}{l}1.00000 \text { and } \\
0.65812\end{array}$ & $\begin{array}{l}1.00000 \text { and } \\
0.61950\end{array}$ & $\begin{array}{l}1.00000 \text { and } \\
0.65234\end{array}$ & $\begin{array}{l}1.00000 \text { and } \\
0.12772\end{array}$ \\
\hline Refinement method & $\begin{array}{l}\text { Full-matrix least- } \\
\text { squares on } \mathrm{F}^{\wedge} 2\end{array}$ & $\begin{array}{l}\text { Full-matrix least- } \\
\text { squares on } \mathrm{F}^{\wedge} 2\end{array}$ & $\begin{array}{l}\text { Full-matrix least- } \\
\text { squares on } \mathrm{F}^{\wedge} 2\end{array}$ & $\begin{array}{l}\text { Full-matrix least- } \\
\text { squares on } \mathrm{F}^{\wedge} 2\end{array}$ & $\begin{array}{l}\text { Full-matrix least- } \\
\text { squares on } \mathrm{F}^{\wedge} 2\end{array}$ \\
\hline $\begin{array}{l}\text { Data / restraints / } \\
\text { parameters }\end{array}$ & $2379 / 0 / 176$ & 4852 / 0 / 273 & 7738 / 0 / 448 & 4145 / 0 / 253 & 11197 / 0 / 581 \\
\hline Goodness-of-fit on $\mathrm{F}^{2}$ & 1.080 & 1.061 & 1.0 & 1.067 & 1.031 \\
\hline $\begin{array}{l}\text { Final } R \text { indices } \\
{[I>2 \operatorname{sigma}(I)]}\end{array}$ & $\begin{array}{l}\mathrm{R} 1=0.0296 \\
\mathrm{wR} 2=0.0797\end{array}$ & $\begin{array}{l}\mathrm{R} 1=0.0566 \\
\mathrm{wR} 2=0.1559\end{array}$ & $\begin{array}{l}\mathrm{R} 1=0.0404 \\
\mathrm{wR} 2=0.1019\end{array}$ & $\begin{array}{l}\mathrm{R} 1=0.0449, \\
\mathrm{wR} 2=0.1249\end{array}$ & $\begin{array}{l}\mathrm{R} 1=0.0663 \\
\mathrm{wR} 2=0.1766\end{array}$ \\
\hline $\mathrm{R}$ indices (all data) & $\begin{array}{l}\mathrm{R} 1=0.0298 \\
\mathrm{wR} 2=0.0801\end{array}$ & $\begin{array}{l}\mathrm{R} 1=0.0712, \\
\mathrm{wR} 2=0.1762\end{array}$ & $\begin{array}{l}\mathrm{R} 1=0.0515 \\
\mathrm{wR} 2=0.1071\end{array}$ & $\begin{array}{l}\mathrm{R} 1=0.0494, \\
\mathrm{wR} 2=0.1296\end{array}$ & $\begin{array}{l}\mathrm{R} 1=0.0726, \\
\mathrm{wR} 2=0.1881\end{array}$ \\
\hline $\begin{array}{l}\text { Absolute structure } \\
\text { parameter }\end{array}$ & $0.645(10)$ & & & & \\
\hline $\begin{array}{l}\text { Largest diff. peak } \\
\text { and hole }\end{array}$ & $\begin{array}{l}0.336 \text { and } \\
-0.570 \text { e. } \AA^{-3}\end{array}$ & $\begin{array}{l}0.966 \text { and } \\
-1.174 \text { e. } \AA^{-3}\end{array}$ & $\begin{array}{l}0.483 \text { and } \\
-0.920 \text { e. } \AA^{-3}\end{array}$ & $\begin{array}{l}1.151 \text { and } \\
-0.710 \text { e. } \AA^{-3}\end{array}$ & $\begin{array}{l}2.988 \text { and } \\
-2.197 \text { e. } \AA^{-3}\end{array}$ \\
\hline
\end{tabular}


$\left.\left.F_{\mathrm{c}}^{2}\right)^{2} / \Sigma\left(w F \mathrm{o}^{4}\right)\right]^{1 / 2}$ respectively. The ORTEP-3 program was used to draw the molecule. Crystallographic data (excluding structure factors) for the structures reported in this paper have been deposited with the Cambridge Crystallographic Data Centre as a supplementary publication, Nos. CCDC 991038 (1), 991040 (2), 991042 (3), 991041 (4), 991039 (5). Copies of the data can be obtained free of charge on application to CCDC, 12 Union Road, Cambridge CB2 1EZ, UK (fax: + (44) 1223-336-033; email: deposit@ccdc.cam.ac.uk).

\section{Results and Discussion}

The bulky phosphinoselenoic amine $\left[\mathrm{Ph}_{2} \mathrm{P}(\mathrm{Se}) \mathrm{NHC}\right.$ $\left.\left(\mathrm{CH}_{3}\right)_{3}\right]$ (1) was prepared in a similar fashion as $\left[\mathrm{Ph}_{2} \mathrm{P}(\mathrm{Se}) \mathrm{NH}-2,6-\mathrm{Me}_{2} \mathrm{C}_{6} \mathrm{H}_{4}\right] . \quad\left[\mathrm{Ph}_{2} \mathrm{P}(\mathrm{Se}) \mathrm{NHCHPh}_{2}\right]$ and $\left[\mathrm{Ph}_{2} \mathrm{P}(\mathrm{Se}) \mathrm{NHCPh}_{3}\right]$ were synthesised in quantitative yield by the treatment of $\left[\mathrm{Ph}_{2} \mathrm{PNHC}\left(\mathrm{CH}_{3}\right)_{3}\right]$ with elemental selenium in 1:2 molar ratio at ambient temperature in THF solvent (scheme 1). ${ }^{35,42}$ Compound $\mathbf{1}$ was characterised using standard analytical/spectroscopic techniques and its solid-state structure was established by single crystal X-ray diffraction analysis.

FT-IR spectrum of compound 1 shows strong absorption bands at $535 \mathrm{~cm}^{-1}$ and $993 \mathrm{~cm}^{-1}$ which can be assigned to the characteristic $\mathrm{P}=\mathrm{Se}$ and $\mathrm{P}-\mathrm{N}$ bond stretching frequencies respectively and these values are comparable with reported values $568 \mathrm{~cm}^{-1}$ and
$901 \mathrm{~cm}^{-1} \cdot{ }^{42}$ In the ${ }^{1} \mathrm{H}$ NMR spectra, resonance signal at $1.36 \mathrm{ppm}$ corresponds to the nine methyl protons of the $t$-butyl group and signal at $2.22 \mathrm{ppm}$ represents the amine $\mathrm{N}-\mathrm{H}$ proton of ligand 1 . Both the values are slightly downfield shifted with respect to the free phosphine amine $\left[\mathrm{Ph}_{2} \mathrm{PNHC}\left(\mathrm{CH}_{3}\right)_{3}\right]$. In the ${ }^{13} \mathrm{C}\left\{{ }^{1} \mathrm{H}\right\}$ NMR spectrum of compound 1 , signals at 54.7 and $31.5 \mathrm{ppm}$ can be best assigned to tertiary carbon atom and methyl carbon atom, respectively. Proton decoupled ${ }^{31} \mathrm{P}\left\{{ }^{1} \mathrm{H}\right\}$ NMR spectra is more informative as compound 1 shows a signal at $46.3 \mathrm{ppm}$ which is slightly downfield shifted from the phosphine amine $\left[\mathrm{Ph}_{2} \mathrm{PNHC}\left(\mathrm{CH}_{3}\right)_{3}\right](28.6 \mathrm{ppm})$ due to addition of the selenium atom to the phosphorus atom.

In the solid-state structure, compound $\mathbf{1}$ crystallises in the orthorhombic $P 22_{1} 2_{1} 2_{1}$ space group, having four molecules in the unit cell. The solid-state structure of compound $\mathbf{1}$ is shown in figure 1. The details of the structural parameters are given in table 1. The $\mathrm{P}=$ Se bond distance is found to be 2.1187(8) $\AA$, which is in good agreement with values we reported previously: $2.1019(8) \AA$ for $\left[\mathrm{Ph}_{2} \mathrm{P}(\mathrm{Se}) \mathrm{NH}\left(2,6-\mathrm{Me}_{2} \mathrm{C}_{6} \mathrm{H}_{4}\right)\right]$, 2.1086(12) $\AA$ for $\left[\mathrm{Ph}_{2} \mathrm{P}(\mathrm{Se}) \mathrm{NHCHPh}_{2}\right]$ and 2.1166(8) $\AA$ for $\left[\mathrm{Ph}_{2} \mathrm{P}(\mathrm{Se}) \mathrm{NHCPh}_{3}\right]$. P1-N1 distance $[1.655(3) \AA]$ and $\mathrm{C} 1-\mathrm{N} 1$ distance [1.494(4) $\mathrm{\AA}$ ] are also similar to those of phosphinoselenoic amides $\left[\mathrm{Ph}_{2} \mathrm{P}(\mathrm{Se}) \mathrm{NHR}\right]$, which we previously reported: P1-N1 1.656(3) $\AA, \mathrm{C} 1-$ $\mathrm{N} 1$ 1.441(4) $\AA$ for $\mathrm{R}=2,6-\mathrm{Me}_{2} \mathrm{C}_{6} \mathrm{H}_{4}, \mathrm{P} 1-\mathrm{N} 1$ 1.642(4) $\AA, \mathrm{C} 1-\mathrm{N} 11.459(6) \AA$ for $\mathrm{R}=\mathrm{CHPh}_{2}$, and $\mathrm{P} 1-\mathrm{N} 1$ 1.664(2) $\AA, \mathrm{C} 1-\mathrm{N} 1$ 1.496(4) $\AA$ for $\left.\mathrm{R}=\mathrm{CPh}_{3}\right){ }^{35,44}$

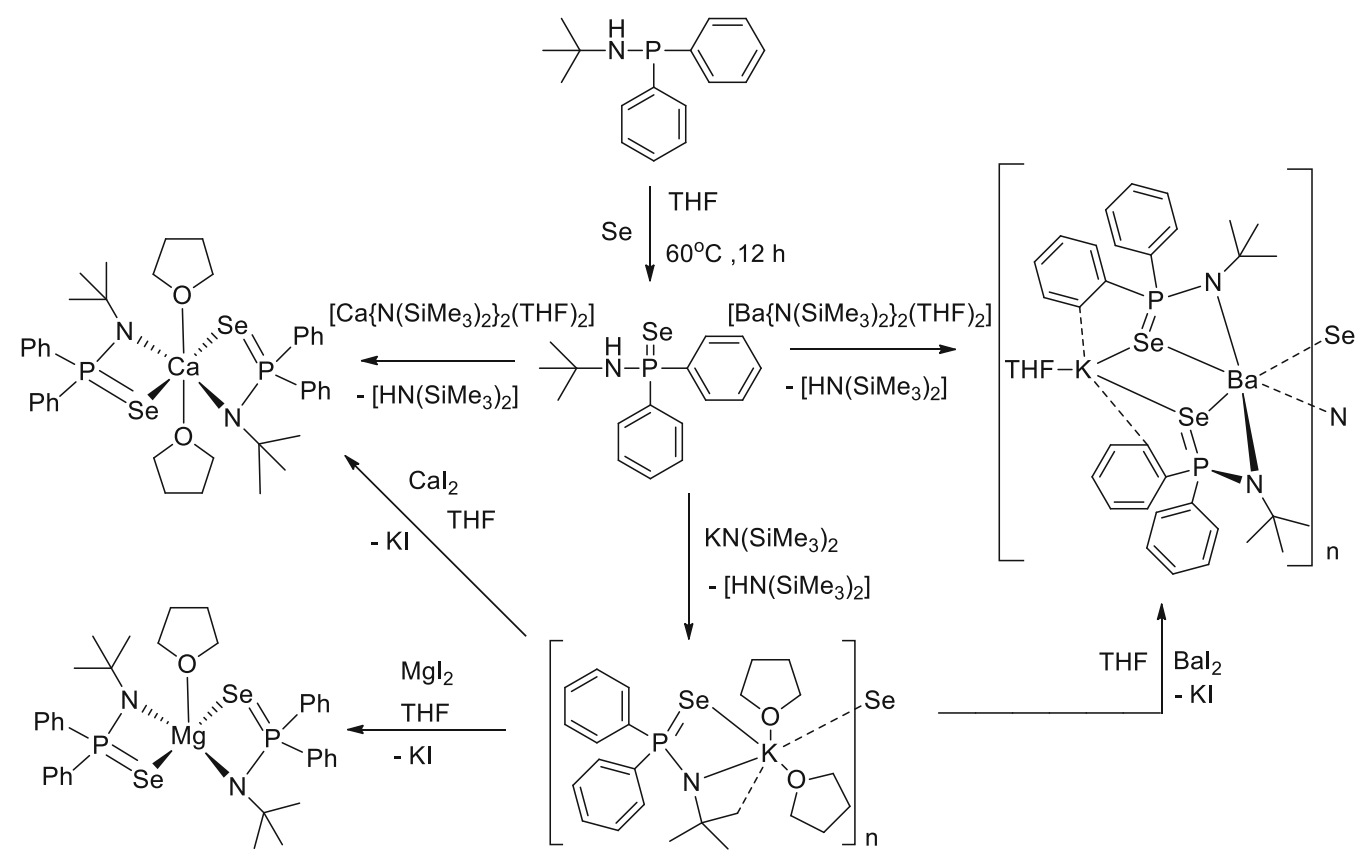

Scheme 1. Synthesis of alkali and alkaline earth metal complexes of phosphinoselenoic amide ligand (1). 


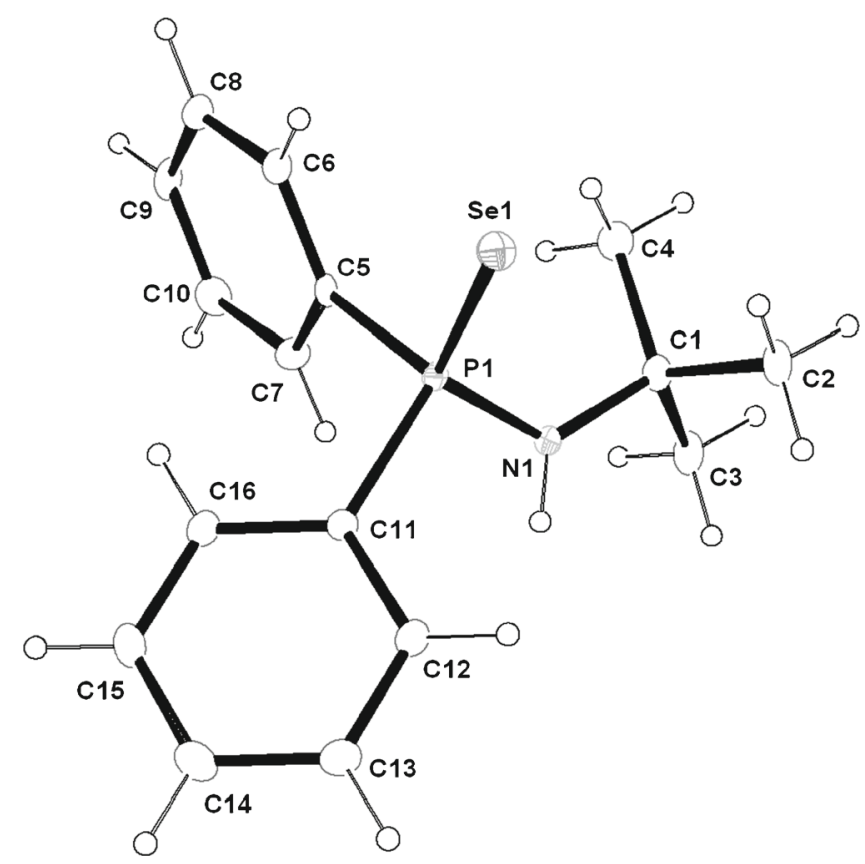

Figure 1. ORTEP diagram of 1 with thermal displacement parameters drawn at the $30 \%$ probability level; hydrogen

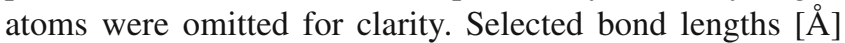
and bond angles $\left[^{\circ}\right]$. P1-N1 1.655(3), P1-Se1 2.1187(8), P1-C5 1.815(3), P1-C11 1.816(3), N1-C1 1.494(4), C1C2 1.533(5), C1-C3 1.526(5), C1-C4 1.529(5), N1-P1-Se1 119.41(10), Se1-P1-C5 112.48(10), Se1-P1-C11 110.70(10), N1-P1-C11 102.22(13), C5-P1-C11 105.15(14), P1-N1-C1 127.6(2), N1-C1-C4 109.9(3), N1-C1-C3 106.1(3), C2-C1C3 109.9(3), C2-C1-C4 110.4(3), N1-C1-C2 110.4(3), C3C1-C4 110.1(3).

\subsection{Potassium complex}

The potassium complex of composition $\left[\mathrm{K}(\mathrm{THF})_{2}\right.$ $\left.\left\{\mathrm{Ph}_{2} \mathrm{P}(\mathrm{Se}) \mathrm{N}\left(\mathrm{CMe}_{3}\right)\right\}\right]_{\mathrm{n}}$ (2) can be readily prepared by the reaction of compound $\mathbf{1}$ and potassium bis(trimethylsilyl)amide in THF through the elimination of volatile bis(trimethylsilyl)amine (scheme 1). Compound 2 was re-crystallised from a mixture of THF/pentane. Air and moisture sensitive compound $\mathbf{2}$ crystallises in the monoclinic $P 2_{1} / \mathrm{c}$ space group, with four molecules in the unit cell. The details of the structural and refinement parameters are given in table 1. The asymmetric unit as well as the polymeric form of compound $\mathbf{2}$ in the solid state is shown in figure 2 . In the asymmetric unit, the central potassium atom is surrounded by one monoanionic ligand 1 coordinating through the selenium and amido nitrogen atoms to form a four-membered metallacycle K1-Se1-P1N1 with angles N1-K1-Se1 of 61.33(6) $\AA$ and N1P1-Se1 of 119.10(13) $\AA$. The K1-Se1 bond distance is $3.3125(10) \AA$ which is in good agreement with the value we previously reported for the potassium salt of ligand
$\left[\mathrm{Ph}_{2} \mathrm{P}(\mathrm{Se}) \mathrm{NCHPh}_{2}\right]^{-}(\mathrm{K}-\mathrm{Se} 3.3090(10) \AA) .{ }^{35}$ The K1$\mathrm{N} 1$ bond distance is 3.047(3) $\AA$ which is slightly elongated compared to the previously reported value of $\mathrm{K}-\mathrm{N}$ $2.725(3) \AA) .{ }^{35}$ The P1-K1 distance is 3.3806(13) $\AA$ and this is slightly shorter than the corresponding distances $3.5579(12) \AA$ in $\left[\left\{(\mathrm{THF})_{2} \mathrm{KPh}_{2} \mathrm{P}(\mathrm{Se}) \mathrm{N}\left(\mathrm{CHPh}_{2}\right)\right\}_{2}\right],{ }^{35}$ $3.5354(14) \AA$ in $\left[\left\{(\mathrm{THF})_{2} \mathrm{KPh}_{2} \mathrm{P}(\mathrm{S}) \mathrm{N}\left(\mathrm{CHPh}_{2}\right)\right\}_{2}\right]^{45}$ and $3.5148(10) \AA$ in $\left[\left\{\left(\mathrm{Ph}_{2} \mathrm{CHNP}\left(\mathrm{BH}_{3}\right) \mathrm{Ph}_{2}\right) \mathrm{K}(\mathrm{THF})_{2}\right\}_{2}\right],{ }^{46}$ which we reported. The $\mathrm{P} 1-\mathrm{K} 1$ distance is within the sum of the covalent radii $(3.45 \AA)$ of potassium and phosphorous atoms, indicating a covalent interaction between them. ${ }^{47}$ The potassium atom also has a weak interaction with one of the methyl carbon atoms of the tertiary butyl group [the $\mathrm{K} 1 \cdots \mathrm{C} 2$ distance is $3.210(5) \AA]$. The one-dimensional polymeric network for complex $\mathbf{2}$ is formed by the extended coordination of the selenium atom with the potassium atom of the neighbouring molecule. The $\mathrm{K}-\mathrm{Se}$ distance of 3.2859(11) $\AA$ is within the range of the values mentioned above. Two additional THF molecules are chelated to the potassium atom, with K1-O1 and K1-O2 bond distances of 2.606(5) $\AA$ and 2.654(3) $\AA$ respectively. Therefore, the geometry of each potassium centre in the polymeric unit is best described as distorted octahedral. It is noteworthy that the polymeric structure for complex 2 was observed, due to the bulky $t$-butyl group on the amido nitrogen, as in contrast only dimeric polymetallacyclic structure for the potassium salt $\left[(\mathrm{THF})_{2} \mathrm{~K}\left\{\mathrm{Ph}_{2} \mathrm{P}(\mathrm{Se}) \mathrm{N}\left(\mathrm{CHPh}_{2}\right)\right\}\right]_{2}$ potassium structure was found by using diphenylmethyl $\left(\mathrm{CHPh}_{2}\right)$ group on the same nitrogen atom, keeping other groups identical in our previous report. ${ }^{35}$ Thus, the presence of the more bulky $t$-butyl group at nitrogen plays an important role in determining the nuclearity of complex 2 . In the solution state, complex $\mathbf{2}$ shows only one set of signals similar to the free ligand $\mathbf{1}$ in the ${ }^{1} \mathrm{H}$, ${ }^{13} \mathrm{C}\left\{{ }^{1} \mathrm{H}\right\}$ and ${ }^{31} \mathrm{P}\left\{{ }^{1} \mathrm{H}\right\}$ NMR spectra, which indicates the dynamic behaviour of complex 2 in the solution state. ${ }^{31} \mathrm{P}\left\{{ }^{1} \mathrm{H}\right\}$ NMR spectra of complex 2 shows single peak at $46.33 \mathrm{ppm}$ which is very similar to ligand $\mathbf{1}$ $(46.30 \mathrm{ppm})$, indicating that there is no influence of the potassium atom on the phosphorous centre of ligand $\mathbf{1}$ upon complex formation.

\subsection{Alkaline earth metal complexes}

The magnesium, calcium and barium complexes $\mathbf{3 , 4}$ and 5 respectively, were prepared in good yield and high purity using two synthetic routes. In the first method, complexes 3-5 were prepared by the reaction of respective alkaline earth metal diiodides $\mathrm{MI}_{2}$ (where $\mathrm{M}=\mathrm{Mg}, \mathrm{Ca}$ and $\mathrm{Ba}$ ) with potassium salt of phosphinoselenoic amide $\left[\mathrm{K}(\mathrm{THF})_{2}\left\{\mathrm{Ph}_{2} \mathrm{P}(\mathrm{Se}) \mathrm{N}\left(\mathrm{CMe}_{3}\right)\right\}\right]_{\mathrm{n}}$ 

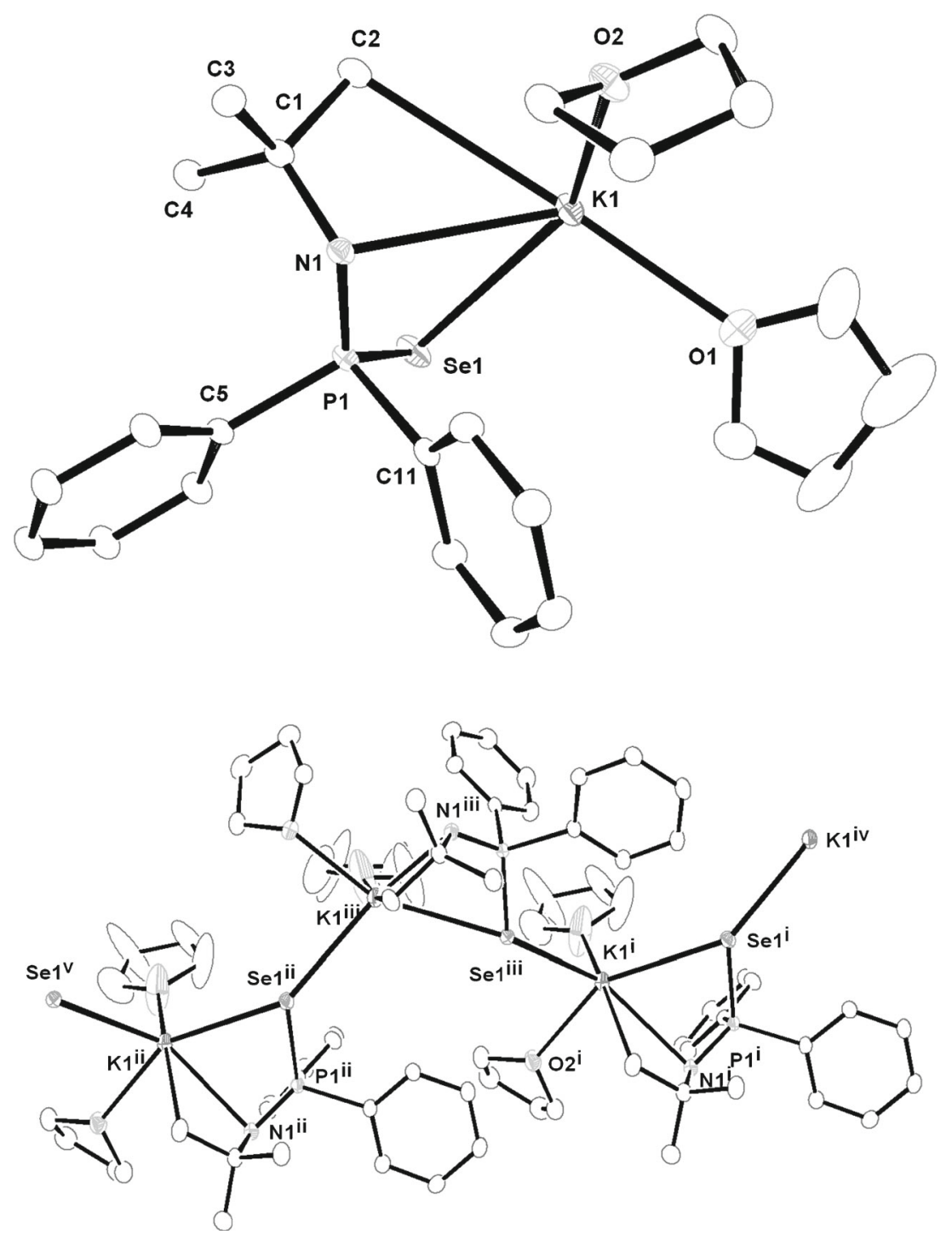

Figure 2. ORTEP diagram of $\mathbf{2}$ with thermal displacement parameters drawn at the $30 \%$ probability level; hydrogen atoms were omitted for clarity. Selected bond lengths $[\AA]$ and bond angles $\left[{ }^{\circ}\right]$. K1-N1 3.047(3), K1-Se1 3.3125(10), K1-O1 2.606(5), K1-O2 2.654(3), K1-C2 3.210(5), P1-N1 1.576(3), P1Se1 2.1792(11),P1-C5 1.842(4), P1-C11 1.825(4), N1-C1 1.476(5), C1C2 1.534(6), C1-C3 1.528(6), C1-C4 1.542(6), P1-N1-K1 87.97(14), C1N1-K1 106.2(2), P1-Se1-K1 72.70(3), N1-K1-Se1 61.33(6), Se1-K1-O1 105.06(18), O1-K1-O2 93.6(2), N1-K1-O2 88.29(10), O1-K1-N1 126.8(2), Se1-K1-O2 149.61(8), N1-P1-C5 114.69(18), C5-P1-C11 100.89(17), C11P1-Se1 108.10(13), N1-P1-Se1 119.10(13), C11-P1-N1 103.72(18), C5-P1Se1 108.42(13), P1-N1-C1 126.3(3), C2-C1-N1 109.8(3), N1-C1-C3 107.0(3), C2-C1-C3 108.5(4), C2-C1-C4 108.3(4), C3-C1-C4 108.4(4).

(2), which was prepared according to the procedure in the literature involving ligand $\mathbf{1}$ and potassium bis(trimethylsilyl)amide. ${ }^{48}$ The second method involved treating the phosphinoselenoic amide (1) directly with calcium bis(trimethylsilyl)amide $\left[\mathrm{Ca}\left\{\mathrm{N}\left(\mathrm{SiMe}_{3}\right)_{2}\right\}\right.$ $\left.{ }_{2}\{\mathrm{THF}\}_{n}\right]$ in THF at ambient temperature to afford the calcium complex of molecular formula $\left[(\mathrm{THF})_{2} \mathrm{Ca}\left\{\eta^{2}-\right.\right.$
$\left.\left.\mathrm{Ph}_{2} \mathrm{P}(\mathrm{Se}) \mathrm{N}\left(\mathrm{CMe}_{3}\right)\right\}_{2}\right]$ (4) (scheme 1). The first route was followed for the three metal complexes 3-5, while the second was followed only for complex 4 . The novel alkaline earth metal complexes 3-5 were characterised using analytical/spectroscopic techniques and the molecular structures of complexes 3-5 were determined by single crystal X-ray diffraction analyses. 
The strong absorption at $570 \mathrm{~cm}^{-1}$ (for 3), $581 \mathrm{~cm}^{-1}$ (for 4) and $576 \mathrm{~cm}^{-1}$ (for 5) in FT-IR spectra indicates the evidence of $\mathrm{P}=\mathrm{Se}$ bond in each complex and the values are very similar to that of the neutral ligand $\mathbf{1}$ $\left(535 \mathrm{~cm}^{-1}\right)$ due to the slight elongation of $\mathrm{P}=$ Se bond bound to the metal centre. In ${ }^{1} \mathrm{H}$ NMR spectra, the amino proton of ligand $\mathbf{1}$, which was present at 2.22 $\mathrm{ppm}$, is absent. Two multiplet signals for each complex at 3.76 and $1.37 \mathrm{ppm}$ (for 4), 3.67 and $1.51 \mathrm{ppm}$ (for 5) can be assigned to the solvated THF molecules coordinated to the metal centre. One set of signals for the phenyl protons are also observed, which is in the same range as that of ligand $\mathbf{1}$, indicating no significant effect of metal atoms on the phenyl groups due to complex formation. In ${ }^{31} \mathrm{P}\left\{{ }^{1} \mathrm{H}\right\}$ NMR spectra, in complexes 3-5, all the phosphorus atoms present in the phosphinoselenoic amide ligand (1) moieties are chemically equivalent and show only one signal at $59.5 \mathrm{ppm}$ (for 3), $37.1 \mathrm{ppm}$ (for 4) and $46.3 \mathrm{ppm}$ (for 5). For compound 3 this value is shifted to downfield and for compound $\mathbf{4}$, shifted up field in comparison to potassium salt 2 (46.3 ppm) and neutral ligand 1 (46.3 ppm). Unlike the magnesium and calcium complexes ( $\mathbf{3}$ and 4), the barium complex 5 shows ${ }^{31} \mathrm{P}\left\{{ }^{1} \mathrm{H}\right\}$ NMR signal at $46.3 \mathrm{ppm}$ which is the same as that of potassium salt $\mathbf{2}$ as well as neutral ligand $\mathbf{1}$ (46.3 ppm). This observation is quite different from our previous studies where we noticed a high downfield shift for the resonance of phosphorus atoms (71.9 ppm for $\mathrm{Ca}, 71.8 \mathrm{ppm}$ for $\mathrm{Sr}$ and 71.9 for $\mathrm{Ba}$ ) bound to heavier alkaline earth metals compared to the free phosphinoselenoicamido ligand $\left[\mathrm{Ph}_{2} \mathrm{P}(\mathrm{Se}) \mathrm{NCHPh}_{2}\right]^{-}(58.0 \mathrm{ppm}) .^{35}$

In the solid state, the magnesium complex 3 crystallises in the monoclinic $P 2_{1} / \mathrm{c}$ space group, with four molecules in the unit cell. The details of the structural parameters for compound $\mathbf{3}$ are given in table 1. The molecular structure of compound $\mathbf{3}$ is shown in figure 3 . In magnesium complex $\mathbf{3}$, the coordination polyhedron is formed by two monoanionic $\left[\mathrm{Ph}_{2} \mathrm{P}(\mathrm{Se}) \mathrm{N}\left(\mathrm{CMe}_{3}\right)\right]^{-}$ligands, and one THF molecule. Each $\left[\mathrm{Ph}_{2} \mathrm{P}(\mathrm{Se}) \mathrm{N}\left(\mathrm{CMe}_{3}\right)\right]^{-}$ligand coordinates to the magnesium atom through the chelation of one selenium atom and one amido nitrogen atom. The $\mathrm{P}-$ $\mathrm{Mg}$ distance of 2.9963(14) $\AA$ and 2.9987(14) $\AA$ is slightly greater than the average $\mathrm{Mg}-\mathrm{P}$ coordination bond $(2.667 \AA)$ and thus a weak interaction between them was observed. ${ }^{49}$ Thus the $\left[\mathrm{Ph}_{2} \mathrm{P}(\mathrm{Se}) \mathrm{N}\left(\mathrm{CMe}_{3}\right)\right]^{-}$ group can be considered a bi-dentate ligand. The geometry around the central magnesium atom can be best described as a distorted square pyramidal, having two amido nitrogen and two selenium atoms of two $\left[\mathrm{Ph}_{2} \mathrm{P}(\mathrm{Se}) \mathrm{N}\left(\mathrm{CMe}_{3}\right)\right]^{-}$moieties in the basal plane and the oxygen atom from the THF molecule at the axial position. Two four-membered metallacycles N1$\mathrm{P} 1-\mathrm{Se} 1-\mathrm{Mg} 1$ and N2-P2-Se2-Mg1 are formed and a dihedral angle of $40.6^{\circ}$ is observed between the two mean planes, having $\mathrm{N} 1, \mathrm{P} 1, \mathrm{Se} 1$ and $\mathrm{Mg} 1$, and N2, P2, $\mathrm{Se} 2$ and $\mathrm{Mg} 1$ atoms respectively.

The most interesting thing is that the magnesiumselenium bond distances [Mg1-Se1 2.6964(12) $\AA$ and $\mathrm{Mg} 1-\mathrm{Se} 22.7056(12) \AA]$ are slightly elongated in comparison to previously reported value of $2.536(3) \AA$ for the compound $\left[\mathrm{Mg}\left(\mathrm{SeMes}^{*}\right)_{2}(\mathrm{THF})_{2}\right]$ (where Mes* $=$ 2,4,6- $\left.t-\mathrm{Bu}_{3} \mathrm{C}_{6} \mathrm{H}_{2}\right){ }^{27}$ This is mainly due to the steric bulk on the backbone of the phosphineamido ligand moiety. The magnesium-nitrogen distances $[\mathrm{Mg} 1-\mathrm{N} 1$ 2.169(3) $\AA$ and $\mathrm{Mg} 1-\mathrm{N} 2$ 2.145(3) $\AA$ ] were observed for compound 3 ; these are slightly longer when compared to the $\mathrm{Mg}-\mathrm{N}$ bond reported in the literature. For example, the $\mathrm{Mg}-\mathrm{N}$ bond distance was reported as $1.970(3) \AA$ for $\left[\left\{\left(\mathrm{L}^{\mathrm{iPr}}\right)_{2} \mathrm{Mg}(\mathrm{THF})_{2}\right\}\right.$. (THF) $]$, $2.094(3) \AA$ for $\left[\left\{\left(\mathrm{L}^{\mathrm{iPr}}\right)_{2} \mathrm{Mg}\right\} \cdot(\mathrm{THF})\right]\left(\right.$ where $\mathrm{L}^{\mathrm{iPr}}=[(2$, 6- $\left.\left.{ }^{\mathrm{i}} \mathrm{Pr}_{2} \mathrm{C}_{6} \mathrm{H}_{3}\right) \mathrm{NC}(\mathrm{Me})\right]_{2}$ ) and $2.051(2) \AA$ for $\left[\left(\mathrm{L}^{\mathrm{Mes}}\right)_{2}\right.$ $\left.\mathrm{Mg}(\mathrm{THF})_{3}\right]$ and $2.070(2) \AA$ for $\left[\left(\mathrm{L}^{\mathrm{Mes}}\right)_{2} \mathrm{Mg}\right.$ ] (where $\left.\mathrm{L}^{\text {Mes }}=\left[\left(2,4,6 \quad \mathrm{Me}_{3} \mathrm{C}_{6} \mathrm{H}_{2}\right) \mathrm{NC}(\mathrm{Me})\right]_{2}\right){ }^{50}$ Recently, we also synthesised magnesium complex of the type $[\mathrm{Mg}$ $\left.\left\{\mathrm{C}_{2} \mathrm{H}_{4}\left(\mathrm{NPh}_{2} \mathrm{P}(\mathrm{Se})\right)_{2}\right\}\{\mathrm{THF})_{3}\right]$ in which we observed $\mathrm{Mg}-\mathrm{N}$ distances of 2.066(3) $\AA$ and 2.083(3) $\AA$, which is well in agreement with the reported values, but slightly shorter than the observed values $2.169(3) \AA$ and 2.145(3) $\AA$ for complex 3. The P-Se bond distances [2.1567(9) $\AA$ and 2.1581(9) $\AA$ ] and $\mathrm{P}-\mathrm{N}$ bond distances [1.606(3) $\AA$ and 1.602(3) $\AA$ ] are within the range for alkaline earth metal complexes that we previously reported: P-Se distance 2.1449(18) $\AA$ for $\mathrm{Ca}, 2.1477(12) \AA$ for $\mathrm{Sr}$ and 2.152(2) $\AA$ for $\mathrm{Ba}$, and $\mathrm{P}-\mathrm{N}$ distance 1.631(6) $\AA$ for $\mathrm{Ca}, 1.610(3) \AA$ for $\mathrm{Sr}$ and 1.609(7) $\AA$ for $\mathrm{Ba}^{35}$

In contrast to the magnesium complex $\mathbf{3}$ the homoleptic calcium complex $\mathbf{4}$ crystallises in the triclinic space group $P-1$, with one molecule in the unit cell. The details of the structural parameters are given in table 1 . The solid state structure of complex 4 is shown in figure 4. In accordance with alkaline earth metal complexes, we previously reported $\left[\mathrm{M}\left\{\mathrm{Ph}_{2} \mathrm{P}(\mathrm{Se}) \mathrm{NCHPh}_{2}\right\}_{2}(\mathrm{THF})_{2}\right]$ (where $\mathrm{M}=\mathrm{Ca}$ and $\mathrm{Sr}$ ), in the calcium complex $\mathbf{4}$, the coordination polyhedron is formed by two $\left[\mathrm{Ph}_{2} \mathrm{P}(\mathrm{Se}) \mathrm{N}\left(\mathrm{CMe}_{3}\right)\right]^{-}$ligands, and two THF molecules which are trans to each other. Therefore, the calcium atom adopts a distorted octahedral geometry. The structural differences between the magnesium and calcium complexes can be explained by the larger ionic radius of $\mathrm{Ca}^{2+}(0.99 \AA)$ compared to that of $\mathrm{Mg}^{2+}(0.72 \AA) .{ }^{51}$ The $\mathrm{Ca}-\mathrm{Se}$ bond distance of 2.9619(3) $\AA$ observed in complex 4 is quite long, compared to the magnesium analogue [(2.6964(12) 


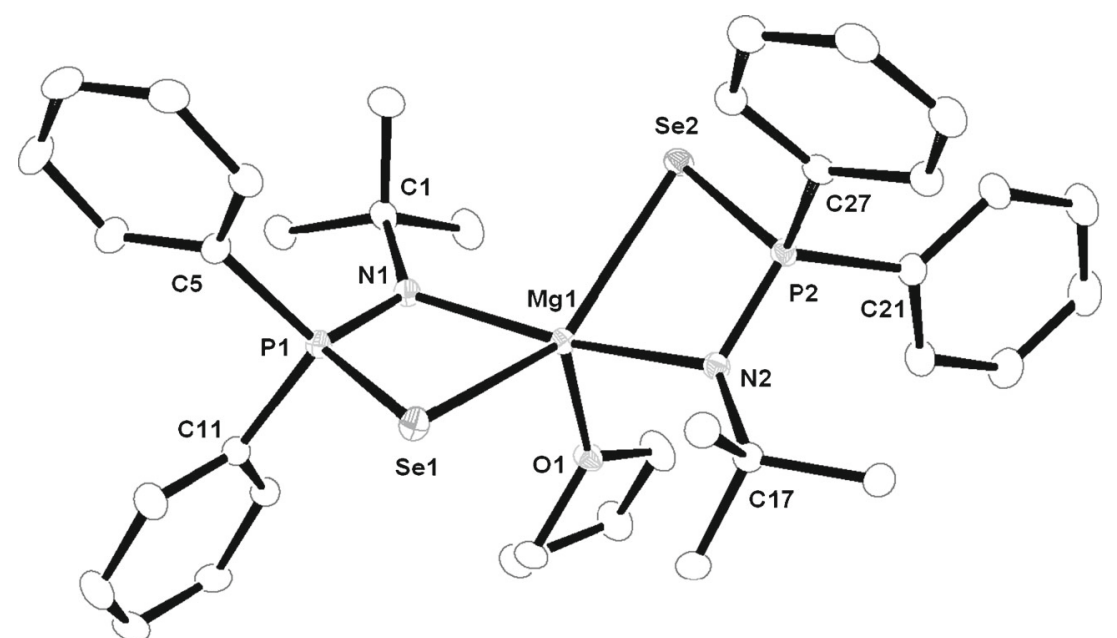

Figure 3. ORTEP diagram of $\mathbf{4}$ with thermal displacement parameters drawn at the $30 \%$ probability level; hydrogen atoms were omitted for clarity. Selected bond lengths $[\AA]$ and bond angles $\left[^{\circ}\right] . \mathrm{Mg} 1-\mathrm{N} 2$ 2.145(3), Mg1Se2 2.7056(12), Mg1-O1 2.067(3), Mg1-N1 2.169(3), Mg1-Se1 2.6964(12), P1-Se1 2.1567(9), P1-N1 1.606(3), N1-C1 1.496(4), P1-C5 1.828(4), P1C11 1.827(4), P2-N2 1.602(3), P2-Se2 2.1581(9), P2-C21 1.825(4), P2-C27 1.834(4), N2-C17 1.497(4), Mg1-Se2-P2 75.19(3), Mg1-N2-P2 105.39(14), N2-Mg1-Se2 74.99(8), N2-Mg1-O1 95.95(11), O1-Mg1-Se1 107.81(8), Se2Mg1-N1 100.90(8), Se1-Mg1-N1 75.40(8), Mg1-Se1-P1 75.34(3), Mg1-N1-P1 104.11(14), Mg1-N1-C1 129.4(2), N1-P1-Se1 105.03(10), P1-N1-C1 129.4(2), Se1-P1-C11 105.55(12), N1-P1-C5 116.52(16), C5-P1-C11 103.97(17), Se1P1-C5 109.51(12), N1-P1-C11 115.73(16), C21-P2-C27 105.86(17), N2-P2C21 115.08(16), Se2-P2-C27 110.60(11), N2-P2-Se2 104.18(10), N2-P2-C27 114.30(15), Se2-P2-C21 106.61(12).

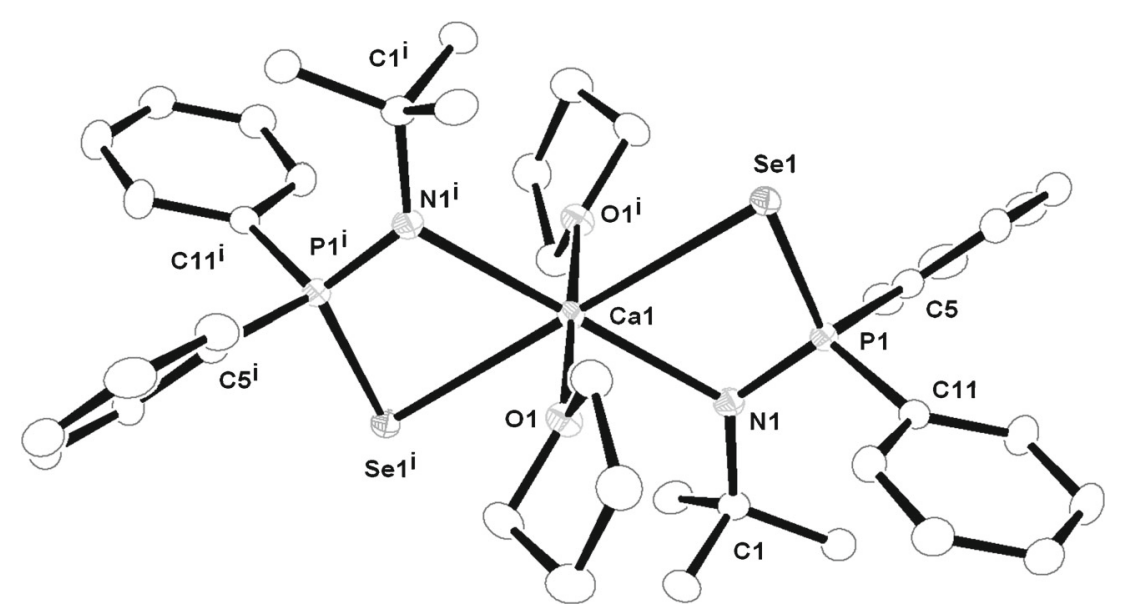

Figure 4. ORTEP diagram of $\mathbf{4}$ with thermal displacement parameters drawn at the $30 \%$ probability level; hydrogen atoms were omitted for clarity. Selected bond lengths $[\AA]$ and bond angles $\left[^{\circ}\right]$. Ca1-N1 2.451(3), Ca1-Se1 2.9619(3), Ca1-O1 2.465(2), Ca1-O1 ${ }^{\mathrm{i}}$ 2.465(2), Ca1-Se1 ${ }^{\mathrm{i}}$ 2.9619(3), Ca1-N1 ${ }^{\mathrm{i}}$ 2.451(3), P1-N1 1.591(3), P1-Se1 2.1706(8), N1-C1 1.495(4), P1-C5 1.835(3), P1C11 1.835(3). Ca1-N1-C1 126.33(19), P1-N1-Ca1 105.15(13), P1-Se1-Ca1 76.91(2), N1-Ca1-Se1 68.73(6), N1-Ca1-O1 92.66(8), O1-Ca1-Se1 ${ }^{\mathrm{i} 92.66(8),}$

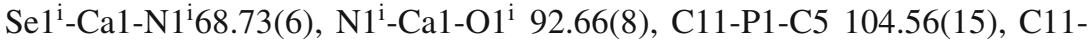
P1-N1 112.89(14), N1-P1-Se1 109.19(10), C5-P1-N1 115.73(16), C11-P1-Se1 107.43(10), P1-N1-C1 126.9(2). 

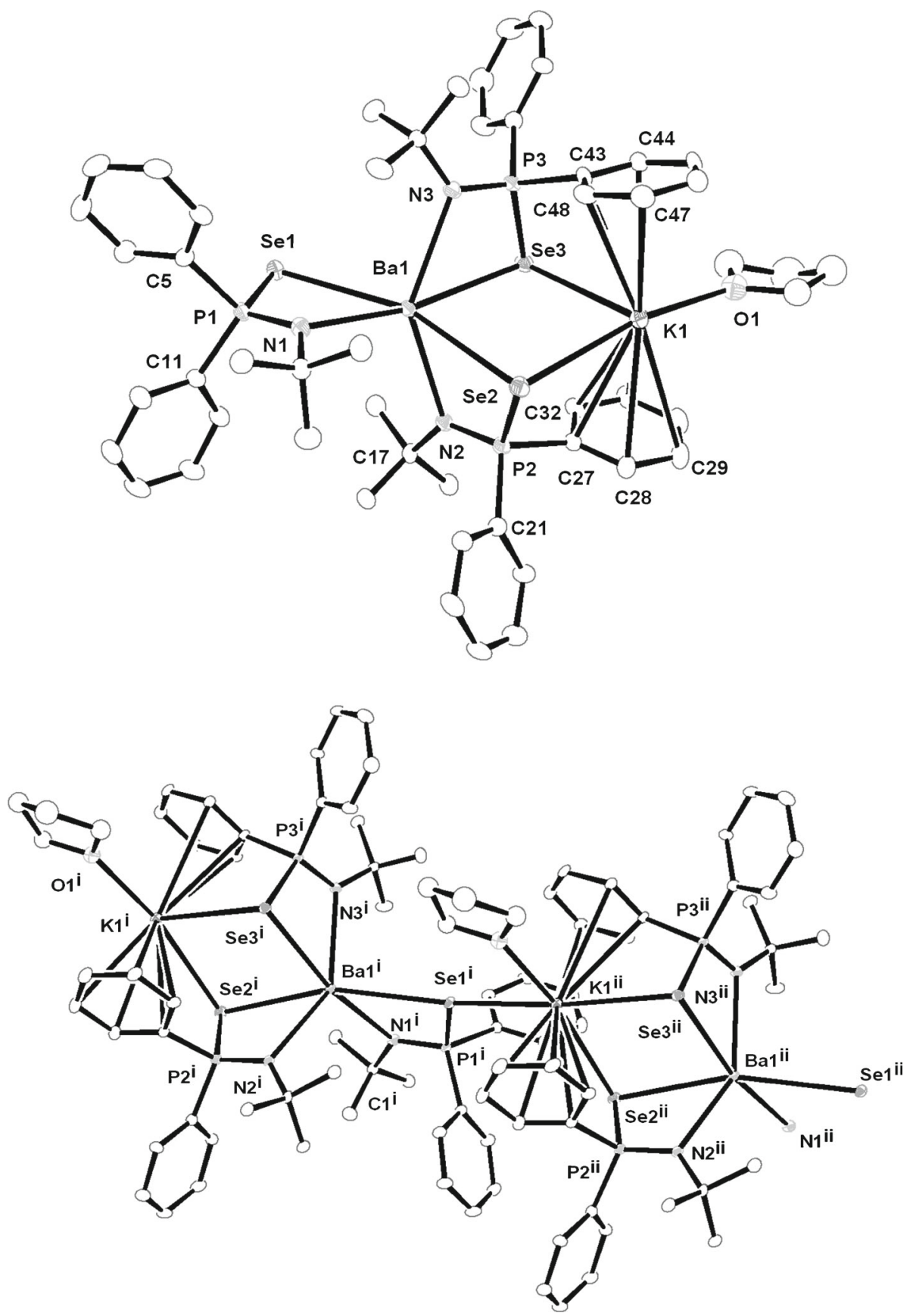

Figure 5. ORTEP diagram of $\mathbf{5}$ with thermal displacement parameters drawn at the $30 \%$ probability level; hydrogen atoms were omitted for clarity. Selected bond lengths $[\AA]$ and bond angles $\left[^{\circ}\right]$. Ba1-Se2 3.3203(7), Ba1-Se3 3.3518(7), Ba1-N2 2.790(5),Ba1-N3 2.789(5),Ba1-Se1 3.3274(7), Ba1-N1 2.774(5), O1-K1 2.731(6), K1-Se3 3.4175(15), K1-Se2 3.3627(15),P1-N1 1.603(5), P1-Se1 2.1681(16), N1-C1 1.491(8), P1-C11 1.825(6), P1-C5 1.826(6), P2-Se2 2.1681(15), P2-C27 1.835(6), P2-C21 1.852(6), P2-N2 1.577(5), N2-C17 1.488(7), P3-Se3 2.1692(15), P3-N3 1.593(5), N3-C33 1.490(8), P3-C37 1.829(6), P3-C43 1.838(6), N3-C33 1.490(8). K1-Se3-Ba1 96.20(3), K1-Se2-Ba1 97.86(3), Se2-Ba1-Se3 82.865(18), P2-Se2Ba1 79.80(4), P2-N2-Ba1 109.3(2), N2-Ba1-Se2 59.95(10), Se3-Ba1-N3 59.78(10) , N3-Ba1-Se1 95.75(10), N1-Ba1-Se1 59.68(11), N1-Ba1-N2 106.15(15), Ba1Se1-P1 80.57(4), Ba1-N1-P1 110.7(2),Ba1-N1-C1 119.3(4),Ba1-N3-P3 109.9(2), Ba1-N3-C33 122.5(3), O1-K1-Se3 101.11(13), O1-K1-Se2 168.59(14), Se2-K1-Se3 81.26(3),N1-P1-Se1 108.26(19), P1-N1-C1 126.5(4), Se1-P1-C5 105.8(2), N1-P1C11 114.1(3), C5-P1-C11 103.6(3), N1-P1-C5 115.8(3). 
and $2.7056(12) \AA]$ due to the larger ionic radius of the $\mathrm{Ca}^{2+}$ ion. The observed $\mathrm{Ca}-\mathrm{Se}$ bond distance [2.9619(3) $\AA$ ] is within the range of $\mathrm{Ca}-\mathrm{Se}$ distances $[2.9889(8) \AA]$ of the structurally characterised complex $\left[\mathrm{Ca}\left\{\mathrm{Ph}_{2} \mathrm{P}(\mathrm{Se}) \mathrm{NCHPh}_{2}\right\}_{2}(\mathrm{THF})_{2}\right]$ reported by us. ${ }^{35}$ In the literature, we find 2.945(1) $\AA$ reported for $\left[(\mathrm{THF})_{2} \mathrm{Ca}\left\{(\mathrm{PyCH})(\mathrm{Se}) \mathrm{PPh}_{2}\right\}_{2}\right],{ }^{26} 2.93 \AA$ to $3.00 \AA$ reported for $\left[(\mathrm{THF})_{4} \mathrm{Ca}\left(\mathrm{SeMes}^{\prime}\right)_{2}\right]$ and 2.958(2) $\AA$ to $3.001(2) \AA$ reported for $\left[(\mathrm{THF})_{2} \mathrm{Ca}\left(\mathrm{Se}_{2} \mathrm{PPh}_{2}\right)_{2}\right]{ }^{16,23}$ The $\mathrm{Ca}-\mathrm{N}$ distance $[2.451(3) \AA$ is slightly longer compared to the calcium-nitrogen covalent bond reported in the literature [2.361(2) $\AA$ and 2.335(2) $\AA$ ] reported for $\left[\mathrm{Ca}\left(\mathrm{Dipp}_{2} \mathrm{DAD}\right)(\mathrm{THF})_{4}\right]\left(\right.$ Dipp $_{2} \mathrm{DAD}=$ N,N'-bis(2,6-diisopropylphenyl)-1,4-diaza-1,3-butadiene. ${ }^{19}$ The P-Ca distance $[3.2516(8) \AA]$ is too long to consider any interaction between them.

Unlike the magnesium and calcium complexes $\mathbf{3}$ and 4, barium metal forms an 'ate' complex of molecular formula $\left[\mathrm{K}(\mathrm{THF}) \mathrm{Ba}\left\{\mathrm{Ph}_{2} \mathrm{P}(\mathrm{Se}) \mathrm{N}\left(\mathrm{CMe}_{3}\right)\right\}_{3}\right]_{\mathrm{n}}$ (5). This is mainly due to the larger ionic radius of the $\mathrm{Ba}^{2+}$ ion and $t$-butyl group on the nitrogen atom of ligand $\mathbf{1}$ allows the third anionic ligand to coordinate to the barium centre. Complex $\mathbf{5}$ crystallises in the triclinic space group $P-1$, with two molecules in the unit cell. The details of the structural parameters are given in table 1 . The solid state structure of complex $\mathbf{5}$ is shown in figure 5. In the asymmetric unit of complex $\mathbf{5}$, the central $\mathrm{Ba}^{2+}$ ion is surrounded by three anionic ligand 1 moieties, which coordinate with $\mathrm{Ba}^{2+}$ ion through the amide nitrogen and selenium atoms. There is one potassium ion (K1) in complex $\mathbf{5}$, which is $\eta^{3}-$ attachment by two flanking phenyl rings from each of the phosphinoselenoic amide ligand moiety and one THF molecule also coordinated to potassium. In addition, two selenium atoms of the two anionic ligands are coordinated to the potassium ion in the bridging fashion. The geometry of the barium in complex $\mathbf{5}$ is therefore best described as distorted octahedral geometry. The Ba-Se bond distances [3.3274(7) $\AA$, 3.3203(7) $\AA$ and 3.3518(7) $\AA$ ] in complex 5 are within the range of the $\mathrm{Ba}-\mathrm{Se}$ distances $[3.366(1) \AA$ and $3.324(1) \AA]$ for the complex $\left[\left\{\mathrm{BaI}\left(4,5-\left(\mathrm{P}(\mathrm{Se}) \mathrm{Ph}_{2}\right)_{2} \mathrm{tz}\right)\right\}\right.$ $\left.{ }_{2}(\text { thf })_{7}\right]$ reported by Raymundo Cea-Olivares et al. ${ }^{52}$ $3.2787(11) \AA$ for $\left[\mathrm{Ba}(\mathrm{THF})_{4}\left(\mathrm{SeMes}^{*}\right)_{2}\right] \quad\left(\mathrm{Mes}^{*}=\right.$ $\left.2,4,6-t-\mathrm{Bu}_{3} \mathrm{C}_{6} \mathrm{H}_{2}\right)$ and 3.2973(3) $\AA$ for $\left[\left\{\mathrm{Ba}(\mathrm{Py})_{3}\right.\right.$ $\left.\left.(\mathrm{THF})(\text { SeTrip })_{2}\right\}_{2}\right]$ (Trip $\left.=2,4,6-{ }^{\mathrm{i}} \mathrm{Pr}_{3} \mathrm{C}_{6} \mathrm{H}_{2}\right)$ reported by Ruhlandt-Senge et al., ${ }^{34}$ 3.3553(10) $\AA$ and $3.3314(10) \AA$ for $\left[\mathrm{Ba}\left\{\mathrm{Ph}_{2} \mathrm{P}(\mathrm{Se}) \mathrm{NCHPh}_{2}\right\}_{2}(\mathrm{THF})_{2}\right]$, and $3.3842(8) \AA$ for $\left[\left\{\eta^{2}-\mathrm{N}\left(\mathrm{PPh}_{2} \mathrm{Se}\right)_{2}\right\} \quad{ }_{2} \mathrm{Ba}(\mathrm{THF})_{3}\right]$ previously reported by us. ${ }^{34,53}$ The K-Se distances $3.3627(15) \AA$ and $3.4175(15) \AA$ are also within the range $[3.3090(10) \AA]$ for the complex $\left[\left\{(\mathrm{THF})_{2} \mathrm{KPh}_{2} \mathrm{P}(\mathrm{Se}) \mathrm{N}\left(\mathrm{CHPh}_{2}\right)\left\{_{2}\right]\right.\right.$ reported by our group. ${ }^{35}$ The $\mathrm{K}-\mathrm{C}$ distances vary between $3.333(6) \AA$ and $3.336(6) \AA$, which are comparable with the $\mathrm{K}-\mathrm{C}$ bond lengths found in $\left[\left(\mathrm{L}^{\mathrm{Mes}}\right)_{2}^{2-} \mathrm{Mg}\left(\eta^{6}: \eta^{6}-\right.\right.$ $\left.\left.\mathrm{K}(\mathrm{THF})_{2}\right)\right]\left[\mathrm{K}(\mathrm{THF})_{6}\right] \cdot(\mathrm{THF})_{2}$ where $\mathrm{L}^{\text {Mes }}=[(2,4,6-$ $\left.\left.\mathrm{Me}_{3} \mathrm{C}_{6} \mathrm{H}_{2}\right) \mathrm{NC}(\mathrm{Me})\right]_{2} \quad(3.127 \AA \text { and } 3.259 \AA)^{50}$ and $\left[\left\{(\mathrm{THF})_{2} \mathrm{~K}\left(\mu-\mathrm{N}(\mathrm{Ph})^{\mathrm{i}} \mathrm{Pr}\right)_{2}\right\}_{2} \mathrm{Ca}\right](3.156(2)-3.259(2) \AA)$ with the slipped $\eta^{6}$-coordination. ${ }^{54-60}$ The average distance of $\mathrm{K} \cdots$ phenyl ring is about $3.127 \AA$ and Ba...K separation is about $5.039 \AA$ which allows the potassium ion to interact with the selenium atom [K1$\left.\mathrm{Se}^{\#} 3.3259(15) \AA\right]$ of the neighbouring unit to grow the one dimesional polymer. Thus we observed that larger ion radii $\left(\mathrm{K}^{+}\right.$and $\left.\mathrm{Ba}^{2+}\right)$ form polymeric complexes with ligand 1. The P-Se bond [2.1681(16) $\AA$, $2.1681(15) \AA$ and $2.1692(15) \AA]$ is slightly longer [2.1187(8) $\AA$ for ligand 1] upon coordination of the selenium and barium atoms. A weak interaction between barium and phosphorus [Ba1-P1 3.6617(15), Ba1-P2 3.6299(15) and Ba1-P3 3.6520(14)] was also observed. The $\mathrm{Ba}-\mathrm{N}$ distances [2.774(5) $\mathrm{A}, 2.790(5) \AA$ and 2.789(5) $\mathrm{A}]$ are similar to the values [2.777(6) $\AA$ and 2.778(6) $\AA$ ] for $\left[\mathrm{Ba}\left(\mathrm{Ph}_{2} \mathrm{P}(\mathrm{Se}) \mathrm{NCHPh}_{2}\right)_{2}(\mathrm{THF})_{2}\right]$, 2.733(6) $\AA$ for $\left[\mathrm{Ba}\left(\mathrm{Ph}_{2} \mathrm{P}\left(\mathrm{BH}_{3}\right) \mathrm{NCHPh}_{2}\right)_{2}(\mathrm{THF})_{2}\right]$ reported by $\mathrm{us}^{35}$ and 2.720(4) $\AA$ and 2.706(4) $\AA$ for $[\mathrm{Ba}$ $\left.\left((\text { Dip })_{2} \mathrm{DAD}\right)(\mu-\mathrm{I})(\mathrm{THF})_{2}\right]_{2}$ reported in the literature. ${ }^{18}$

\section{Conclusion}

We have demonstrated the monomeric and polymeric alkali metal and alkaline earth metal complexes with phosphinoselenoic amide ligand $\mathbf{1}$, and in each complex direct metal selenium is observed. In the solid state, due to differences in the ionic radii of the metal centres, the magnesium complex adopts a square pyramidal geometry, whereas the calcium complex adopts a distorted octahedral geometry with the phosphinoselenoic amide ligand. Since the barium atom is the largest in terms of ionic radii amongst $\mathrm{Mg}, \mathrm{Ca}$ and $\mathrm{Ba}$, a polymeric ate-complex of molecular formula $\left[\mathrm{K}(\mathrm{THF}) \mathrm{Ba}\left\{\mathrm{Ph}_{2} \mathrm{P}(\mathrm{Se}) \mathrm{N}\left(\mathrm{CMe}_{3}\right)\right\}_{3}\right]_{\mathrm{n}}$ is obtained. The unique feature of ligand $\mathbf{1}$, with three potential donor atoms, nitrogen, phosphorus and selenium, makes a clear distinction in molecular structure among the alkali and alkaline earth metal complexes. Further reactivity studies on these complexes are underway in our laboratory.

\section{Supplementary Information (SI)}

The ${ }^{1} \mathrm{H}$ and ${ }^{13} \mathrm{C}\left\{{ }^{1} \mathrm{H}\right\}$ NMR spectra of compounds 1$\mathbf{5}$ are given in supplementary information available at www.ias.ac.in/chemsci. 


\section{Acknowledgements}

This work was supported by the Council of Scientific and Industrial Research (CSIR) under project no. 01(2530)/11/EMR-11 and start-up grant from IIT Hyderabad. J.B., R.K.K. thank the University Grants Commission, India, and H. A thanks to CSIR India, for their PhD fellowships.

\section{References}

1. Harder S 2010 Chem. Rev. 1103852

2. Kobayashi S and Yamashita Y 2011 Acc. Chem. Res. 44 58

3. Cahours A 1860 Liebigs Ann. Chem.114 227

4. Grignard V C R 1900 Hebd. Seances Acad. Sci.130 1322

5. Dechy-Cabaret O, Martin-Vaca B and Bourissou D 2004 Chem. Rev. 1046147

6. Thomas C M 2010 Chem. Soc. Rev. 39165

7. Xu X, Chen Y, Zou G, Ma Z and Li G $2010 \mathrm{~J}$. Organomet. Chem. 6951155

8. Sarazin Y, Rosca D, Poirier V, Roisnel T, Silvestru A, Maron L and Carpentier J-F 2010 Organometallics 29 6569

9. Sarazin Y, Liu B, Roisnel T, Maron L and Carpentier J-F 2011 J. Am. Chem. Soc. 1339069

10. Jochmann P, Dols T S, Spaniol T P, Perrin L, Maron L and Okuda J 2009 Angew. Chem. Int. Ed. 485715 (and the references therein)

11. Chisholm M H, Gallucci J C and Phomphrai K 2004 Inorg. Chem. $\mathbf{4 3} 6717$

12. Caro C F, Hitchcock P B and Lappertm M F 1999 Chem. Commun. 1433

13. Harder S 2002 Organometallics 213782

14. Datta S, Roesky P W and Blechert S 2007 Organometallics 264392

15. Jenter J, Koppe R and Roesky P W 2011 Organometallics 301404

16. Hao H, Bhandari S, Ding Y, Roesky H W, Magull J, Schmidt H G, Noltemeyer M and Cui C 2002 Eur. J. Inorg. Chem. 1060

17. Matsuo Y, Tsurugi H, Yamagata T and Mashima K 2003 Bull. Chem. Soc. Jpn. 761965

18. Panda T K, Yamamoto K, Yamamoto K, Kaneko H, Yang Y, TsurugiH and Mashima K 2012 Organometallics 312268

19. Panda T K, Kaneko H, Michel O, Tsurugi H, Pal K, Toernroos K W, Anwander R and Mashima K 2012 Organometallics $\mathbf{3 1} 3178$

20. Caulton K G and Hubert-Pfalzgraf L G 1990 Chem. Rev. 90969

21. Hanusa T P 1993 Chem. Rev. 931023

22. Ruhlandt-Senge K 1995 Inorg. Chem. 343499

23. Ruhlandt-Senge K, Davis K, Dalai S, Englich U and Senge M O 1995 Inorg. Chem. 342587

24. Ruhlandt-Senge K and Englich U 2000 Chem. Eur. J. 6 4063
25. Englich U and Ruhlandt-Senge K 2001 Z. Anorg. Allg. Chem. 627851

26. Kling C, Ott H, Schwab G and Stalke D 2008 Organometallics 275038

27. Gindelberger D E and Arnold J 1994 Inorg. Chem. 33 6293

28. Al-Shboul T M A, Volland G, Gorls H, Krieck S and Westerhausen M 2012 Inorg.Chem. 517903

29. Henke K and Atwood D A 1998 Inorg. Chem. 37224

30. Chadwick S, Englich U and Ruhlandt-Senge K 1998 Chem. Commun. 2149

31. Banbury F A, Davidson M G, Martin A, Raithby P R, Snaith R, Verhorevoort K L and Wright D S $1992 J$. Chem. Soc. Chem. Commun. 1152

32. Mikulcik P, Raithby P R, Snaith R and Wright D S 1991 Angew. Chem. Int. Ed. $\mathbf{3 0} 428$

33. Purdy A P, Berry A D and George C F 1997 Inorg. Chem. 363370

34. Ruhlandt-Senge K and Englich U 2000 Chem. Eur. J. 6 4063

35. Kottalanka R K, Naktode K, Anga S, Nayek H P and Panda T K 2013 Dalton Trans. 424947

36. Murugavel R, Pothiraja R, Shanmugan S, Singh N and Butcher R J J. Organomet. Chem. 20076921920

37. Pourayoubi M, Bayraq S S, Tarahhomi A, Nečas M, Fejfarová K and Dušek M 2014 J. Organomet. Chem. $\mathbf{7 5 1 5 0 8}$

38. Ahman J and Somfai P 1995 Syn. Commun. 252301

39. Boncella J M, Coston C J and Cammack J K 1991 Polyhedron 10769

40. Tanner P S, Burkey D J and Hanusa T P 1995 Polyhedron 14331

41. Kühl O, Blaurock S, Sieler J and Hey-Hawkins E 2001 Polyhedron 20111

42. Altomare A, Burla M C, Camalli G, Cascarano G, Giacovazzo C, Gualiardi A, Polidori G 1994 J. Appl. Cryst. 27, 435

43. Sheldrick G M 2008 Acta Cryst. A64 112-122

44. Naktode K, Kottalanka R K and Panda T K 2012 New. J. Chem. 362280

45. Kottalanka R K, Naktode $\mathrm{K}$, Anga $\mathrm{S}$ and Panda $\mathrm{T}$ K 2013 Phosphorus Sulfur Rel. Elem. in press. DOI: 10.1080/10426507.2013.818998

46. Kottalanka R K, Anga S, Naktode K, Laskar P, Nayek H P and Panda T K 2013 Organometallics 324473

47. Housecroft C E and Sharpe A G 2005 In Inorganic Chemistry $2^{\text {nd }}$ ed.; (NJ: Prentice Hall) p 135

48. Bhattacharyya P, Slawin A M Z, Williams D and Woollins J D 1995 J. Chem. Soc., Dalton Trans. 2489

49. Karsch H H and Reisky M 1998 Eur J. Inorg. Chem. 905 2911

50. Gao J, Liu Y, Zhao Y, Yang X-J and Sui Y 2011 Organometallics 306071

51. Greenwood N N and Earnshaw A 1984 In Chemistry of the Elements (Oxford: Pergamon Press)

52. Balanta-Díaz J A, Moya-Cabrera M, Jancik V, MoralesJuárez T J and Cea-Olivares R 2013 Polyhedron 63 167

53. Kottalanka R K, Anga S, Jana S K and Panda T K 2013 J. Organomet. Chem. $\mathbf{7 4 0} 104$

54. Twamley B and Power P P 2000 Angew. Chem. Int. Ed. 393500 
55. Pu, L, Phillips A D, Richards A F, Stender M, Simons R S, Olmstead M M and Power P P $2003 \mathrm{~J} \mathrm{Am.} \mathrm{Chem.}$ Soc.125 11626

56. Richards A F, Brynda M and Power P P 2004 J. Am. Chem. Soc. 12610530

57. Tsai Y-C, Lu D-Y, Lin Y-M, Hwang J-K and Yu J-S K 2007 Chem. Commun. 4125
58. Zhu Z - L, Wang X -P, Olmstead M M and Power P P 2009 Angew. Chem. Int. Ed. 482027

59. Pi C, Wan L, Gu Y, WuH, Wang C, Zheng W, Weng L, Chen Z, Yang X and Wu L 2009 Organometallics 28 5281

60. Glock C, Görls H and Westerhausen M 2009 Inorg. Chem. 48394 